\title{
Transport and outflow to the North Atlantic in the lower marine troposphere during ICARTT 2004
}

S. R. Davis ${ }^{1}$, R. Talbot ${ }^{2}$, and H. Mao ${ }^{3}$

${ }^{1}$ Institute for the Study of Earth, Ocean, and Space, University of New Hampshire, Durham, $\mathrm{NH}$, USA

${ }^{2}$ Department of Earth and Atmospheric Sciences, University of Houston, Houston, TX, USA ${ }^{3}$ Department of Chemistry, SUNY-College of Environmental Sciences and Forestry, Syracuse, NY, USA

Received: 10 August 2011 - Accepted: 8 December 2011 - Published: 25 January 2012 Correspondence to: S. Davis (sd@sr.gust.unh.edu)

Published by Copernicus Publications on behalf of the European Geosciences Union.

Transport and outflow to the North Atlantic during ICARTT 2004

S. R. Davis et al.

\section{Title Page}

Abstract Introduction

Conclusions References

Tables Figures

14

4

Back

Full Screen / Esc

Printer-friendly Version

Interactive Discussion 


\section{Abstract}

An analysis of pollution plumes emitted from sources in the Northeastern US was based on observations from the International Consortium for Atmospheric Research on Transport and Transformation (ICARTT) 2004 field campaign. Particular attention 5 was given to the relation of these plumes to coastal transport patterns in lower tropospheric layers throughout the Gulf of Maine (GOM) and their contribution to large-scale pollution outflow from the North American continent. Using measurements obtained during a series of flights of the NOAA WP-3D and the NASA DC-8, a unique quasilagrangian case study was conducted for a freshly emitted plume emanating from the New York City source region in late July 2004. The initial development of this plume stemmed from the accumulation of boundary layer pollutants within a coastal residual layer where weak synoptic forcing triggered its advection by mean southwesterly flow. As the plume tracked into the GOM, analysis showed that the plume layer vertical structure evolved into an internal boundary layer form, with signatures of steep vertical gradients in temperature, moisture and wind speed often resulting in periodic turbulence. This structure remained well-defined during the plume study, allowing for the detachment of the plume layer from the surface and thus minimal deposition and plume-sea surface exchange. In contrast, lateral mixing with other low-level plumes was significant during its transit and facilitated in part by persistent shear driven turbulence which further contributed to the high spatial variability in trace gas mixing ratios. The impact of the plume inland was assessed using observations from the AIRMAP air quality network. This impact was noticeably detected as a contribution to poor surface ozone conditions and significant elevations of other major pollutants to levels equaling the highest observed that summer. Further contributions to larger-scale outflow across the North Atlantic was also observed and analyzed.

\section{Transport and outflow to the North Atlantic during ICARTT 2004}

S. R. Davis et al.

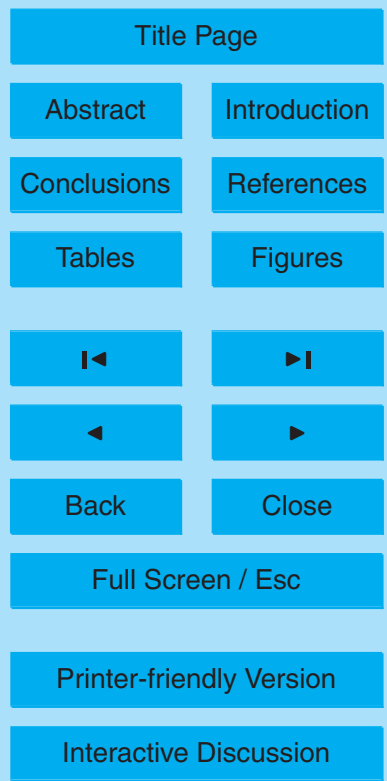




\section{Introduction}

The composition and dynamics associated with pollution plumes released from coastal source regions is of eminent importance to regional air quality and larger scale continental outflow. Over the Northeastern coast of the US, this is especially true, where 5 pollution plumes are regularly emitted from urban/industrial sources along the East Coast that directly impact downwind locations in coastal New England and Eastern Canada (Mao and Talbot, 2004a; Millet et al., 2006; Angevine et al., 2006; Mao et al., 2006; Chen et al., 2007). It has further been observed that frequently these plumes contribute to large scale pollution outflow, traveling 100 s to 1000 s of kilometers in sta10 ble lower tropospheric layers over the Atlantic Ocean, eventually adding to aggregated flows of pollutants that comprise North American continental outflow. Like the upper level forms of outflow (i.e. that facilitated by warm conveyor belts), these flows can measurably influence the composition of the marine atmosphere as well as surface conditions in western and central Europe (Stohl and Trickl, 1999; Stohl et al., 2001;

15 Eckardt et al., 2004; Simmonds et al. 2004).

Low level outflow (LLO) is a form of continental outflow which is achieved within the lower tropospheric layers and occasionally the marine atmospheric boundary layer (MABL) itself. In previous studies, LLO has been identified as pollutant flow leaving the continent and traveling below $3 \mathrm{~km}$ in altitude (Daum et al., 1998; Owen et al., 2006). Such case of outflow can result from a variety of forcing mechanisms. Cooper et al. (2002) identified the post-cold front air stream as one common mechanism of ventilation into shallow layers of the troposphere during the passage of weaker low pressure systems and full mid-latitude cyclones. Case studies of lower tropospheric transport over the North Atlantic during the summer of 2003 by Owen et al. (2006) suggested a range of meteorological conditions may lead to the onset of LLO events. Employing Lagrangian model simulations in support of observations at PICO NARE, Owen et al. (2006) analyzed three cases of LLO in response to forcing of North American pollution into the lower free troposphere $(0-2 \mathrm{~km})$ by weak synoptic activity and the

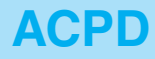

$12,2395-2434,2012$

\section{Transport and outflow to the North Atlantic during ICARTT 2004}

S. R. Davis et al.

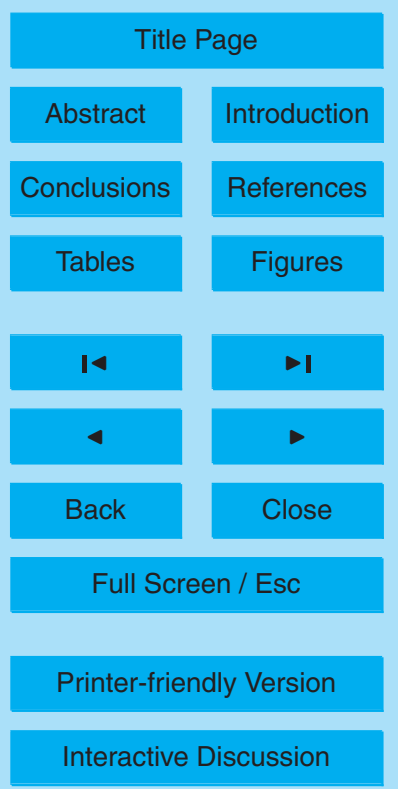


maintenance of shallow detached layers across the Atlantic.

Most similar instances of LLO begin as regional scale processes where pollutant laden continental air masses undergo significant transformations at the coastal boundary as they move into the marine atmosphere. These transformations are forced by

5 abrupt land-sea differences in roughness lengths, vertical moisture and heat fluxes, as well as surface temperature gradients present along the coastline (Angevine et al 1997, 2002, 2006; Owen et al 2005; Millet et al., 2006). Numerous efforts have described such scenarios, including the recent study by Dacre et al. (2007) which connected shallow ventilation and boundary layer trace gas transport to local mesoscale processes 10 such as the sea-breeze and regional coastal land-sea flow patterns. In such scenarios, pollutants are deposited into the shallow residual layers over cold North Atlantic waters. These residual layers often evolve into a stable internal boundary layer (SIBL) above the marine boundary layer and the cold North Atlantic waters (Garratt, 1990; Angevine et al., 2006). Importantly, this further implies that LLO and the shallow ven15 tilation of boundary layer pollutants may then occur in the absence of strong, synoptic scale forcing events.

Recent efforts have shown that influence of LLO events on regional as well as intercontinental transport has been significant. In regional analyses, Chen et al. (2007) employed principal component analysis in determining that $58 \%$ of the variance of the airmasses influencing northern New England was associated with emissions from nearby coastal source regions such as Boston and NYC. Over larger scales, Li et al. (2005) concluded from extensive model simulations that $30 \%$ of the North American $\mathrm{CO}$ exported in the summertime occurs below $3 \mathrm{~km}$ in altitude.

These findings provide motivation for the present study which builds upon previous efforts to better understand LLO and coastal circulation as transport pathways of the North American continental outflow, and the dynamics of the lower troposphere/MABL that facilitate it. The NOAA WP-3D flights in particular during the ICARTT campaign yielded invaluable observations of the composition and structure associated with low level pollution transport from the Eastern US during the summer of 2004. Of these

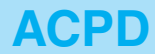

12, 2395-2434, 2012

\section{Transport and outflow to the North Atlantic during ICARTT 2004}

S. R. Davis et al.

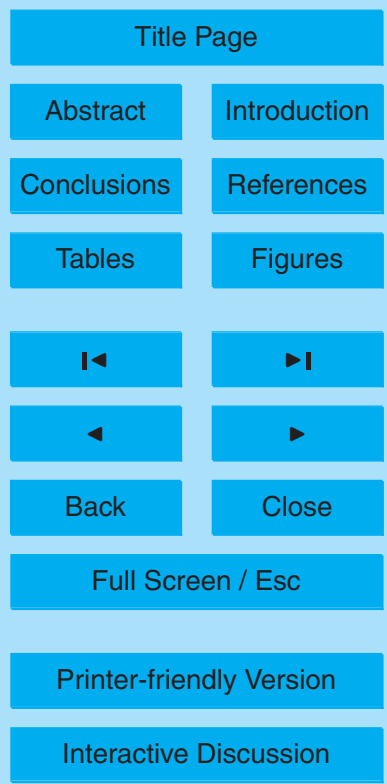


flights, three sequential flights between 20 and 22 July provided the unique opportunity to observe flow of a freshly emitted plume along the northeast coast, into the Gulf of Maine (GOM) and its eventual outflow into the western North Atlantic. Specific objectives of our study were to employ these observations in a quasi-Lagrangian manner to 5 investigate the composition and dynamics of such regional plumes, influences of the local MABL on plume transport, and the contribution of such plumes to North American continental outflow.

\section{Data}

The primary trace gas observations in the coastal and marine atmosphere investigated 10 here were obtained onboard the NOAA WP3-D Orion research aircraft (P-3). In its configuration for the ICARTT 2004 campaign (Fehsenfeld et al., 2006), carbon monoxide (CO) and sulfur dioxide $\left(\mathrm{SO}_{2}\right)$ were measured from sensors on the wing pod with a fastresponse, high-precision vacuum ultraviolet (VUV) resonance fluorescence technique. Ozone $\left(\mathrm{O}_{3}\right)$, nitric oxide $(\mathrm{NO})$, and nitrogen dioxide $\left(\mathrm{NO}_{2}\right)$ were measured onboard by chemiluminescensce methods. Total reactive nitrogen $\left(\mathrm{NO}_{y}\right)$ was determined using a catalytic reduction technique with the aid of an AU converter. In-situ volatile organic carbon compounds (VOC's) were sampled using a proton transfer reaction mass spectrometer with additional can samples measured using a gas chromatograph - mass spectrometer. Chemical ionization mass spectrometers were used in the observation of peroxycarboxylic nitric anhydrides (PANs), nitric acid $\left(\mathrm{HNO}_{3}\right)$, sulfuric acid $\left(\mathrm{H}_{2} \mathrm{SO}_{4}\right)$, and the hydroxyl radical $(\mathrm{OH})$. Corresponding observations of additional physical and chemical parameters taken onboard the NASA DC-8 were further used in the analyses made. This data was freely available at the NASA Earth Missions webpage: http://www.espo.nasa.gov/intex-na/.

25 Surface observations from the AIRMAP measurement network (http://airmap.unh. edu) as shown in figure $2 b$ were used in the assessment of the out-flowing plume impact across northern New England. One minute averages of $\mathrm{CO}, \mathrm{O}_{3}$, and $\mathrm{NO}_{\mathrm{y}}$ 2399

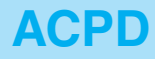

12, 2395-2434, 2012

\section{Transport and outflow to the North Atlantic during ICARTT 2004}

S. R. Davis et al.

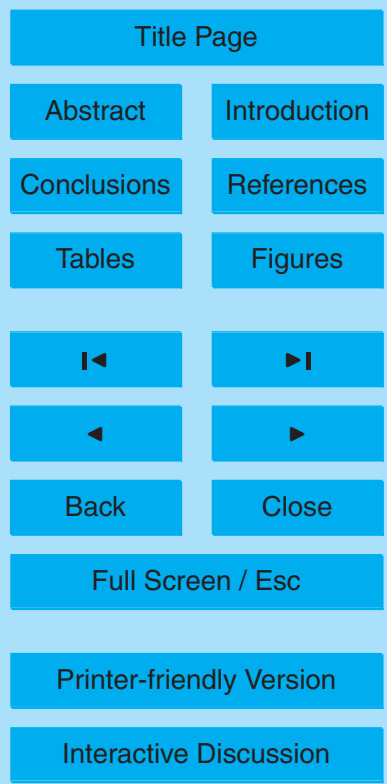


from the AIRMAP observatories at Appledore Island (AIS), Thompson Farm (TFR), and Castle Springs (CSP) during the ICARTT campaign were the primary surface data sets used with additional canister observations incorporated in the evaluation of halocarbon species. The Appledore Island site is situated $15 \mathrm{~km}$ offshore at $\left(42.97^{\circ} \mathrm{N}, 70.62^{\circ} \mathrm{W}\right)$, 5 thereby provided insight into coastal surface conditions. Thompson Farm is located at $43.11^{\circ} \mathrm{N}, 70.95^{\circ} \mathrm{W}$ and is a rural location situated $20 \mathrm{~km}$ from the coast. Castle Springs was similarly rural, located $160 \mathrm{~km}$ from the coast at $43.75^{\circ} \mathrm{N}, 71.35^{\circ} \mathrm{W}$, and was used in the characterization of plume impacts further inland. The period of May, 1st to September 1st, 2004 was used in the statistical description of seasonal surface 10 conditions at each site.

Based on the aircraft observations of meteorological parameters, wind speed, wind direction, water mixing ratio, and potential temperature, further useful parameters were determined to gain insight into the stability and turbulent properties of the plume transport layers. Virtual potential temperature, $\theta_{v}$, is the theoretical potential temperature 15 of dry air that would have the same density as moist air and was calculated by the relationship:

$\theta_{\mathrm{v}}=\theta\left(1+0.6 r-r_{\mathrm{l}}\right)$

using potential temperature and water mixing ratio $\left(r\right.$, water vapor mixing ratio and $r_{1}$, liquid water mixing ratio) measurements. The vertical gradient of the virtual potential 20 temperature was calculated from vertical profiles made during the WP-3D flights to provide information in the stratification stability.

Using the $\theta_{\mathrm{v}}$ profiles and observations of vertical shear in the horizontal wind vectors, the gradient Richardson number, $R_{i}$, was calculated using:

$R i=\frac{\frac{g}{\theta v} \frac{\partial \theta v}{\partial z}}{\left(\frac{\partial U}{\partial z}\right)^{2}+\left(\frac{\partial V}{\partial z}\right)^{2}}$

${ }_{25} R_{j}$ is a nondimensional ratio that relates the buoyant production or consumption of turbulence to the shear production of turbulence within atmospheric layers. In this study, 2400
$12,2395-2434,2012$

\section{Transport and outflow to the North Atlantic during ICARTT 2004}

S. R. Davis et al.

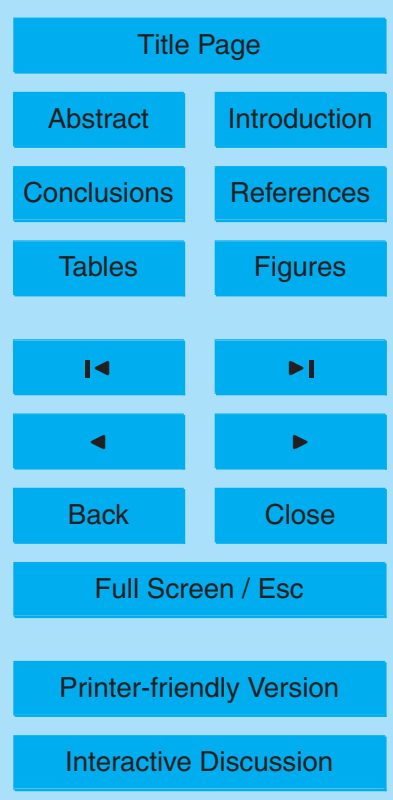


$R_{i}$ was used to gauge dynamic stability and the formation of turbulence within a layer. A value of $R_{i}=0.25$ has been established as a critical value separating laminar from turbulent behavior in most geophysical flows. This is based on solutions to the TaylorGoldstein form of the linearized Navier-Stokes equation quasi-2dimensional flows as 5 described in Kundu (2004). Below the 0.25 value, shear driven Kelvin-Helmholtz instability is manifested forcing turbulent characteristics in the flow.

Observations of wind speed (instantaneous and 5 second averages) and wind direction were also employed to calculate the turbulent kinetic energy (TKE) within layers:

$\frac{\mathrm{TKE}}{m}=\bar{e}=0.5\left(\overline{u^{\prime 2}}+\overline{v^{\prime 2}}+\overline{w^{\prime 2}}\right)$

10 As shown, this is the mean kinetic energy per unit mass associated with eddies and turbulent motion within a given layer.

\section{Results and discussion}

A total of sixteen research flights were conducted by the NOAA P3 aircraft between 5 July and 14 August 2004 in conjunction with the ICARTT campaign. Three of these

15 flights were flown between 20 and 22 July (hereafter flights 20, 21, and 22 July respectively) to provide a quasi-Lagrangian vantage point of a fresh plume (hereafter the 20 July plume) emitted from the NYC source region as it transited through the GOM and into the Western North Atlantic.

\subsection{Development of the plume}

The 20 July plume case study was characteristic of a low-flowing fresh plume, ventilated into shallow tropospheric layers by weak synoptic forcing. Regional lower tropospheric conditions captured by the National Center for Environmental Prediction (NCEP) analyses of surface pressure, and $10 \mathrm{~m}$ wind vectors during the Lagrangian
ACPD

12, 2395-2434, 2012

\section{Transport and outflow to the North \\ Atlantic during \\ ICARTT 2004}

S. R. Davis et al.

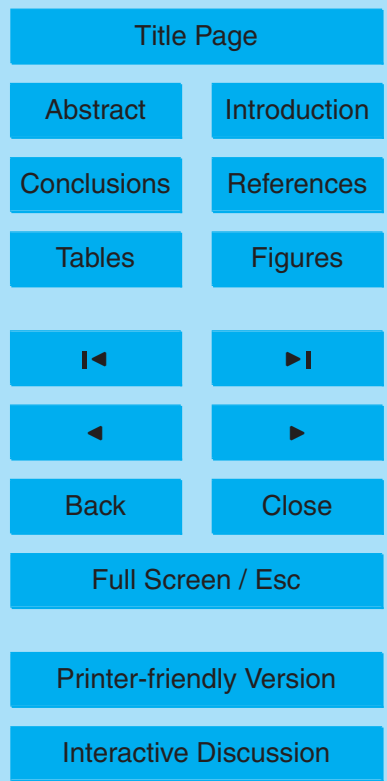


experimental timeframe reflect a slow southwesterly flow off the east coast from Virginia to Newfoundland (Fig. 1a). This flow was established primarily under the influences of the Bermuda High to the southeast of the source region and the Canadian low pressure system initially centered to the northwest along the northern edge of Hudson

5 Bay. Upper level patterns similarly depicted the influence of these large-scale features within the region with the jet stream maintained northwest of the Great Lakes supplying a relative northeasterly flow aloft. The "trigger" for the ventilation of the plume was the development of a mild mesoscale low pressure trough between these larger synoptic features over the mid-Atlantic states developing near the surface as the Canadian Low translates progressively eastward during the 21 and 22 July (Fig. 1b, c).

\subsection{Day 1: initial characterization of the low-level plume}

\subsubsection{Chemical composition near Long Island Sound}

Initial encounters by the P-3 with the plume occurred on 20 July. Departing at 14:00 UTC, this first mission in the three day experiment conducted an eight hour sur15 vey of the plume, making multiple crossings between Long Island Sound (LIS) and the southern GOM as depicted in Fig. 2. During the flight, the physical and chemical signatures of the plume were distinct near the NYC source region and coastal atmosphere surrounding LIS. Above these waters and throughout the immediate Atlantic coastline, a series of vertical profiles between 15:30 UTC and 18:30 UTC observed the plume as 20 a polluted airmass residing within a $1500 \mathrm{~m}$ thick layer at a mean altitude of $1000 \mathrm{~m}$ above the surface and flowing with a southwesterly trajectory.

Figure 3 shows the initial structure of the 20 July plume as distinguished in the 18:30 UTC vertical profile of its primary constituent species: $\mathrm{CO}, \mathrm{O}_{3}, \mathrm{SO}_{2}$, and $\mathrm{HNO}_{3}$. The vertical center of the plume was detected at a height of $1300 \mathrm{~m}$, coinciding with a peak in the $\mathrm{CO}$ mixing ratio (170 ppbv) and an accompanying elevation in $\mathrm{O}_{3}$ (76 ppbv). Further extremes in industrial/urban indicators were observed at this altitude, including pronounced enhancements in toluene (798 pptv), methyl ethyl ketone

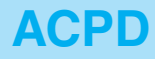

12, 2395-2434, 2012

\section{Transport and outflow to the North Atlantic during ICARTT 2004}

S. R. Davis et al.

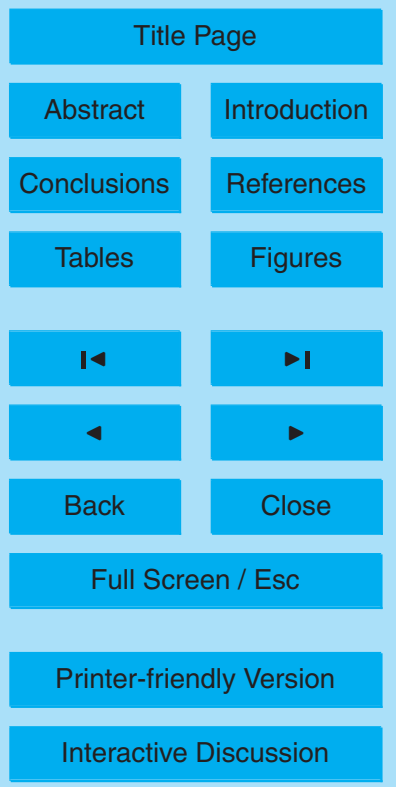


(MEK) (1268 pptv), and benzene (268 pptv) (Table 1) which are characteristically emitted from heavy industry (solvent use) and automobile emissions. An elevation to $2.9 \mathrm{ppbv}$ in $\mathrm{SO}_{2}$ in the plume's vertical center was also observed and likely derived from regional power plant emissions.

5 Observations of enhanced mixing ratios of reactive nitrogen were similarly made in the plume's core over NYC, with $\mathrm{NO}_{\mathrm{y}}$ measuring $3.0 \mathrm{ppbv}$ and predominantly comprised of $\mathrm{HNO}_{3}(2.8 \mathrm{ppbv})$. Following the method set forth in Kleinman et al. (2008) and more recently pursued in Slowik et al. (2011), the photochemical age of the plume was estimated in terms of these observations. Specifically, the $\mathrm{NO}_{\mathrm{x}}-\mathrm{NO}_{\mathrm{y}}$ ratio was 10 employed in the relation:

$$
\text { age } \cong-\log \left(\left[\mathrm{NO}_{\mathrm{x}}\right] /\left[\mathrm{NO}_{\mathrm{y}}\right]\right.
$$

As detailed in the reference works, a value of 0 is indicative of fresh emissions while 1 represents photochemical aging of 1 day or more. For the 20 July plume, mean mixing ratios of $\mathrm{NO}$ and $\mathrm{NO}_{2}$ were $0.035 \mathrm{ppbv}$ and $0.16 \mathrm{ppbv}$ respectively in the plume core over NYC. Mean $\mathrm{NO}_{\mathrm{x}}$ levels were then $0.195 \mathrm{ppbv}$ establishing a mean $\mathrm{NO}_{\mathrm{x}} / \mathrm{NO}_{\mathrm{y}}$ ratio of 0.0676 and a corresponding approximate photochemical age of 1-2 days. Twoday NOAA HYSPLIT Lagrangian back trajectories supported this conclusion, indicating that the plume followed a shallow recirculation over coastal and eastern New York, Pennsylvania, and New Jersey during the two days prior to the initial P3 intercept as 20 shown in Fig. 4.

The relationships between the primary trace gas constituents in the plume were further examined to provide additional insight into its origins and relative background mixing ratios of the species in the lower troposphere over LIS. Considering CO as a general indicator of combustion, its correlation with $\mathrm{O}_{3}$ was employed to gauge photochemical processing within polluted airmasses. Initial encounters with the plume on 20 July suggested that $\mathrm{O}_{3}$ and $\mathrm{CO}$ were well correlated (correlation coefficient of 0.83 ) in close proximity to the NYC source region above LIS. As shown in Fig. 5a (black markers), $\mathrm{O}_{3} / \mathrm{CO}$ ratios within the plume profile near the source region displayed a strong

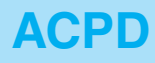

12, 2395-2434, 2012

\section{Transport and outflow to the North Atlantic during ICARTT 2004}

S. R. Davis et al.

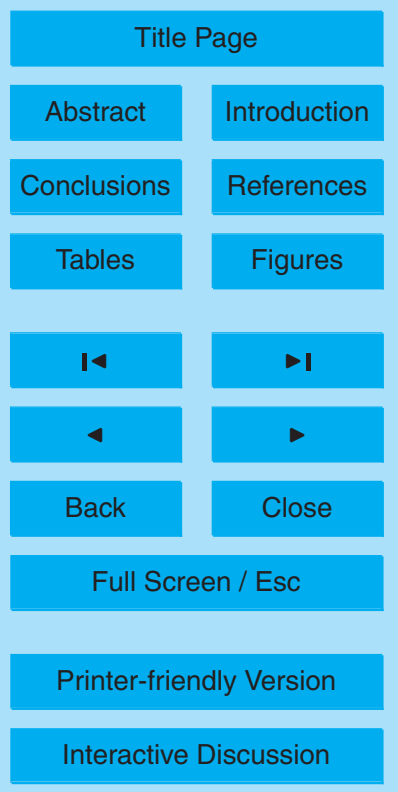


linear relationship, with a regression slope of 0.21 and corresponding correlation coefficient $\left(r^{2}\right)$ of 0.53 . This slope is slightly less than the 0.26 values observed by Daum et al. (1996) in similar low flying plumes emanating from the northeastern US and tracked over the Atlantic during the 1993 North Atlantic Regional Experiment (NARE)

5 a decade earlier. This finding maintain the trend of $\mathrm{O}_{3} / \mathrm{CO}$ slopes being significantly less in plumes over the North Atlantic than over coastal and inland locations. Specific cases include Mao and Talbot (2004b) who observed mean summertime $\mathrm{O}_{3} / \mathrm{CO}$ slopes of 0.37 using three years of data from AIRMAP surface sites and Chin et al. (1994), who determined a mean 0.3 slope to be typical within photochemically aged airmasses 10 found in lower tropospheric layers above summertime North America.

The $\mathrm{O}_{3} / \mathrm{NO}_{y}$ relationships derived from the same vertical profiles similarly exhibited correlation between the species. However, some variability resulted from probable depositional losses of $\mathrm{NO}_{y}$ species and possible mixing of aged and fresher emissions within the plume given its two day history. In the 18:30 UTC intercepts, it was seen that 15 a weaker linear relationship $\left(r^{2}=0.63\right.$ ) was observed between $\mathrm{O}_{3}$ and $\mathrm{NO}_{\mathrm{y}}$, (Fig. 5c, black markers) suggesting that a mixture of airmasses may have been intercepted during initial plume encounters. At higher $\mathrm{NO}_{\mathrm{y}}$ levels (>8 ppbv), the correlation is clearly higher (0.68), and reflective of recent emissions, while at lower mixing ratios of $\mathrm{NO}_{\mathrm{y}}$ $(<5 \mathrm{ppbv})$, the correlation was less $(0.49)$, more suggestive of photochemically aged 20 airmasses and loss of $\mathrm{NO}_{\mathrm{y}}$ through deposition. The $\mathrm{CO} / \mathrm{NO}_{\mathrm{y}}$ relationship exhibited clear linearity, with a fitted slope of $9.583\left(r^{2}=0.95\right)$ as seen in Fig. 5e. Such close correspondence between $\mathrm{CO}$ and $\mathrm{NO}_{\mathrm{y}}$ is indicative of a common combustion source such as automobiles (Daum et al., 1996).

Analysis of whole air samples (WASs) obtained during the near-source region ver25 tical profiles provided insight into 74 additional chemical species within the 20 July plume (Table 1). Halocarbons in these samples were of particular interest, since they are generally found well mixed in the troposphere except in close proximity to source regions (Blake et al., 2004). Many halocarbons also have relatively long lifetimes, with their primary removal mechanism being their reaction with $\mathrm{OH}$ (Thomson et al.,

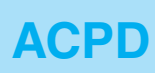

12, 2395-2434, 2012

\section{Transport and outflow to the North Atlantic during ICARTT 2004}

S. R. Davis et al.

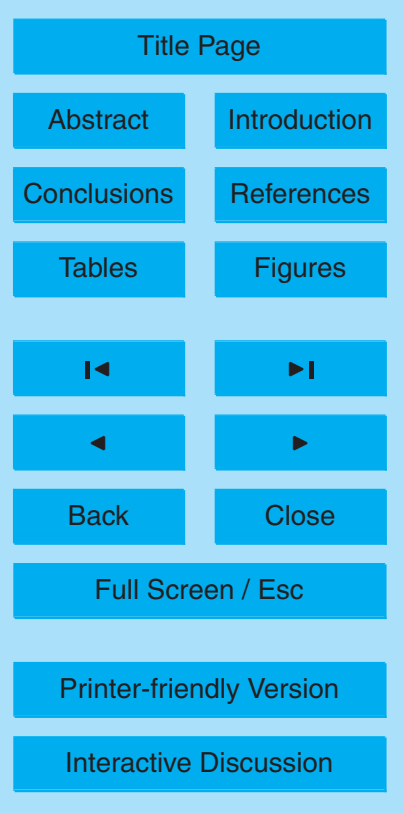


2005). Halocarbon species function well as urban industrial tracers and as seen in this analysis, are a means of tracking the 20 July polluted airmass. Specific halocarbons observed in the 20 Juyy plume included the industrial solvent dichloroethane $\left(\mathrm{C}_{2} \mathrm{H}_{4} \mathrm{Cl}_{2}\right)$, observed at $5.37 \mathrm{pptv}$ within the plume layer, relative to a background mean 5 of 31 pptv observed throughout the remaining flight. Similar enhancements in the level of the dry cleaning agent tetrachloroethylene $\left(\mathrm{C}_{2} \mathrm{Cl}_{4}\right)$ were observed at $188 \mathrm{pptv}$ near the source region. These levels can be compared to a background of $22 \mathrm{pptv}$ determined in other segments of the flight. The heavily used industrial rubber/plastic chloromethane $\left(\mathrm{CH}_{3} \mathrm{Cl}\right)$ also had an enhanced mixing ratio of 531 pptv. Other non10 halocarbon anthropogenic indicators were also present in the NYC WASs, including the refining byproducts ethane ( $2840 \mathrm{pptv}$ ) and ethene ( 936 pptv), along with industrial fuel tracers propane ( 1650 pptv), and acetylene/ethyne ( $\sim 1063 \mathrm{pptv})$.

Correlations between the anthropogenic tracers in the plume WASs and CO were determined as shown in Table 1. At the $95 \%$ confidence level, the correlation coef-

ficients calculated between the two of the most abundant anthropogenic halocarbons within the plume $\left(\mathrm{CH}_{2} \mathrm{Cl}_{2}, \mathrm{C}_{2} \mathrm{Cl}_{4}\right)$ and $\mathrm{CO}$ were above 0.95 . Within the same confidence interval, correlation coefficients between tracers ethane, ethyne, benzene, and propane and $\mathrm{CO}$ also exceeded 0.95 , further reflecting the anthropogenic origin of the plume and the close proximity to the source region.

20 Mixing ratios of non-anthropogenic indicators near the source region in the WASs also supplied insight in terms of plume history and structure. Isoprene, an indicator of air mass exchange with continental vegetation was observed at 800 pptv while dimethyl sulfide (DMS), an indicator of contact with marine surfaces, was detected at a mean of only 12 pptv within the plume. These observations suggest that during the previous days prior to the aircraft intercept, the plume air mass likely experienced some level of exchange with the land surfaces it passed over while only having limited contact or exchange with the sea surface during the same period. This detachment from the ocean surface was more apparent in the vertical profiles of the physical parameters as discussed below.

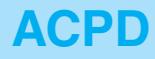

12, 2395-2434, 2012

\section{Transport and outflow to the North Atlantic during ICARTT 2004}

S. R. Davis et al.

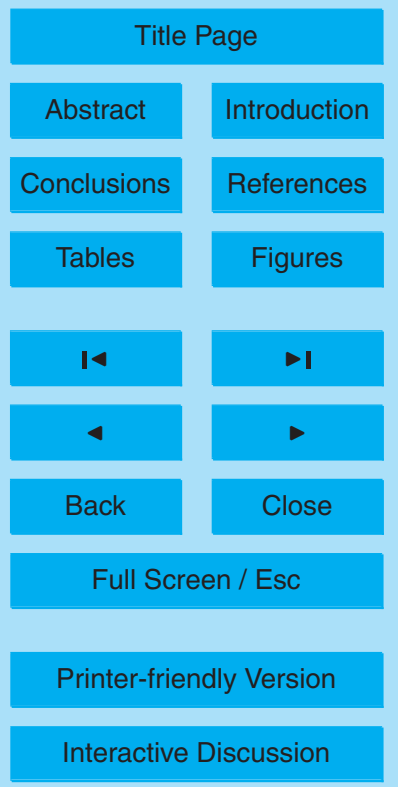




\section{Physical structure of the plume layer}

The noticeable detachment of the 20 July plume from adjacent vertical layers was a key aspect in its behavior as well as its evolution as a low level flow. Model back trajectories (Fig. 4a) and synoptic charts support the hypothesis that the detachment and 5 ventilation of the 20 July plume was linked to the entrainment of continental boundary layer pollutants into a coastal residual layer formed in the lower troposphere rather than through the forcing of a single weather event. In this, the residual layer served as a shallow reservoir for continental pollutants and facilitated their outflow above the marine boundary layer in a detached plume-like fashion over LIS on 20 July. Similar observations of residual layer influences have been established in previous studies, particularly near land-sea transition regions, where buoyancy driven flows such as the land/sea breeze contribute to their development in the coastal atmosphere (Hsu, 1988). Over LIS, residual layers have frequently been found in summer months, when landsea temperature contrasts are larger (Tardiff, 2005) and observed as reservoirs for boundary layer trace gas pollutants during air quality episodes along the East Coast (Zhang et al., 1998). In the study conducted here, data further suggested that the residual layer facilitated the long-range transport achieved by the plume through its advection into the lower troposphere and over the marine boundary layer, thus detaching it from surface interactions in a similar fashion to that described by Dacre et al. (2007) and Foeschetto et al. (2001).

Directly above the source region, the physical state of the atmosphere surrounding the plume was characterized by well-stratified structure with stability evidenced by the profiles of $\theta$ (Fig. 3e, solid black line). The plume containing the residual layer itself was distinguished by a jet-like increase in wind speed centered about a vertical peak of the plume $(1300 \mathrm{~m})$, with a maximum of $10.9 \mathrm{~m} \mathrm{~s}^{-1}$ (Fig. 3f, solid black line). This enhanced wind speed was observed in conjunction with a $\sim 30^{\circ}$ shift in wind direction and a $20 \%$ increase in the water vapor mixing ratio compared to the layers surrounding the plume. The mean dew point temperature of the layer reached $19.3^{\circ} \mathrm{C}$. Despite this

\section{Transport and outflow to the North Atlantic during ICARTT 2004}

S. R. Davis et al.

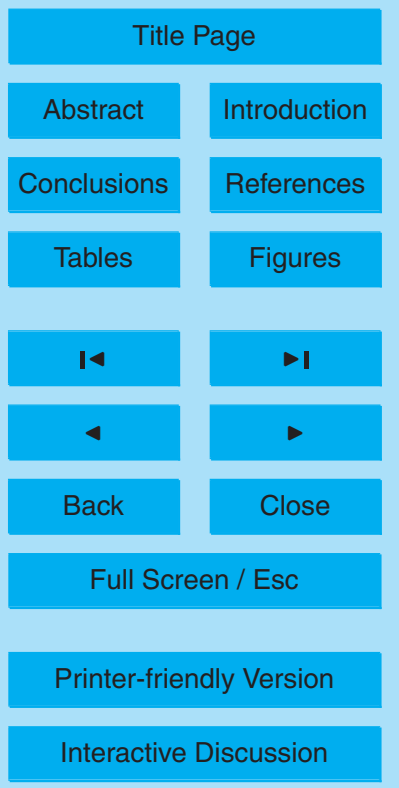


near saturation of the plume layer, shear produced by the sharp vertical gradient in wind speed and direction appeared to also give rise to clear instances of periodic turbulence within it.

A value of 0.25 is considered to be the critical point for the $R_{i}$ separating turbulent and 5 non-turbulent regimes in the atmosphere (Garratt, 1990; Stull, 2008). Conditions favoring turbulence in the plume layers were observed in the near source region profiles, as indicated by values of $R_{i}$ between 0.16 and 0.30 between $600 \mathrm{~m}$ and $1300 \mathrm{~m}$ in altitude (Fig. 3h, solid line). Coupled with this, an increase in vertical velocities was observed, ranging from $0.3-0.5 \mathrm{~m} \mathrm{~s}^{-1}$ (not shown). The enhanced vertical motion was also ob10 served with in the plume layer, which coupled with the vertical gradient in the horizontal wind speed, contributed to significant increases in TKE at the upper and lower bounds of the plume layer ( $1700 \mathrm{~m}$ and $980 \mathrm{~m}$ respectively) (Fig. $3 \mathrm{~g}$ ). These observations were further consistent with the diagnosis of mechanically driven turbulence in the layer, often taking the form of overturning motions associated with Kelvin-Helmholtz instability and leading to the development of small sub-grid scale eddies. The presence of this turbulence is inherent residual layers, and has been seen to influence air quality, via the down-mixing of pollutants during the growth of the mixing layer in the morning (Neu et al., 1994) while Mahrt et al. (1999) suggested that transport within the residual layer is ensured by similar sporadic bursts of turbulence.

Additional aircraft intercepts on 20 July captured the downwind transformation of the plume from an airmass residing in a residual layer to a shallow defined flow en route to the GOM. Induced through the influences of the intense wind shear observed in the lower marine troposphere, radiative cooling by the underlying sea surface, and the onset of the 20-21 July nocturnal transition, initial stages of this transformation were observed at 19:20 UTC, $130 \mathrm{~km}$ downwind of the NYC profile. Subsidence of the plume's vertical center down to $980 \mathrm{~m}$ was evident in the profiles of $\mathrm{O}_{3}, \mathrm{CO}, \mathrm{SO}_{2}$, and $\mathrm{HNO}_{3}$ (Fig. 3a-d, green dotted lines). While horizontal wind speeds were reduced from their NYC magnitudes, significant rises in TKE were recorded in the plume profile and corresponding drops in the $R_{i}$ values between $500 \mathrm{~m}$ and $1500 \mathrm{~m}$ (Fig. 3e-h, green dotted

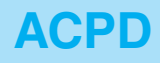

12, 2395-2434, 2012

\section{Transport and outflow to the North Atlantic during ICARTT 2004}

S. R. Davis et al.

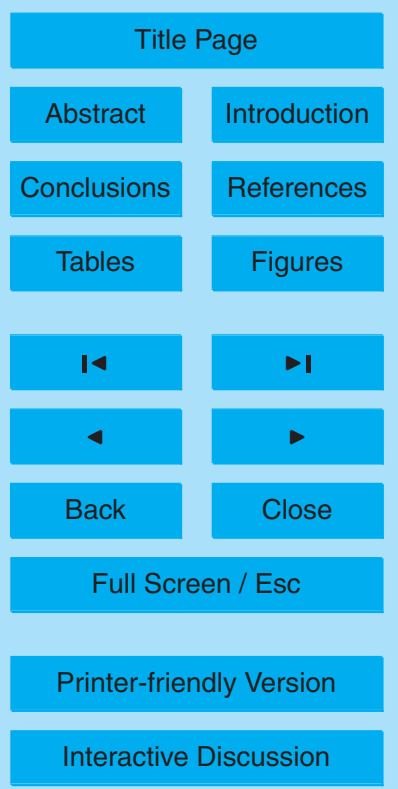


lines) marked episodes of shear driven turbulence as seen earlier. Continued evolution was observed $300 \mathrm{~km}$ downwind as seen in profiles of trace gases and physical parameters observed at 20:00 UTC (Fig. 3a-h, red dashed lines). Between Narragansett Bay and Buzzards Bay, the aircraft observed the 20 July plume as a distinct low level 5 flow, detached from the surface layer and moving steadily out of the southwest. In this new configuration, the plume exhibited a $500 \mathrm{~m}$ thickness, as distinguished in the trace gas profiles. The vertical center could be seen between 250 and $300 \mathrm{~m}$ above the sea surface, where peaks of $\mathrm{O}_{3}, \mathrm{CO}, \mathrm{SO}_{2}$, and $\mathrm{HNO}_{3}$ reached $103 \mathrm{ppbv}, 337 \mathrm{ppbv}$, $6 \mathrm{ppbv}$, and $14 \mathrm{ppbv}$ respectively. A further distinguishable characteristic was a jet-like 10 increase in horizontal wind speed, with maximum amplitudes reaching $12-13 \mathrm{~m} \mathrm{~s}^{-1}$. Resulting horizontal shear contributed greatly to increased TKE $\left(130 \mathrm{~J} \mathrm{~kg}^{-1}\right)$ as well as the persisting low $R_{i}$ values (0-0.3) within the layer, strongly suggesting the continued presence of turbulent motion during the plume's transit.

\subsection{Low-level plume transit and evolution on 21 and 22 July}

15 Forward trajectories computed by the HYSPLIT model are shown in Fig. 4b, projected a southwesterly track for the 20 July plume over the 48 hours following the initial encounters by the P-3. This path was confirmed by Mao et al. (2006) through the analysis of SMART balloon observations which tracked the 20 July plume from the source region to Newfoundland. Further verification of this trajectory was also achieved by multiple 20 intercepts by the P-3 and DC-8 aircraft on 21 and 22 July, which additionally provided observations for the assessment of the plumes transformation. As discussed further below, clear differences in the plume's characteristics and its transformation were observed over the coastal as well as the "open ocean" waters of the GOM region.

\subsection{1 (21 July Day 2)}

25 The NYC plume was readily identifiable during the flights on 21 July through the analysis of the WASs obtained in the lower marine troposphere. As seen in Table 1, the

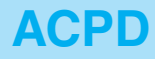

12, 2395-2434, 2012

\section{Transport and outflow to the North Atlantic during ICARTT 2004}

S. R. Davis et al.

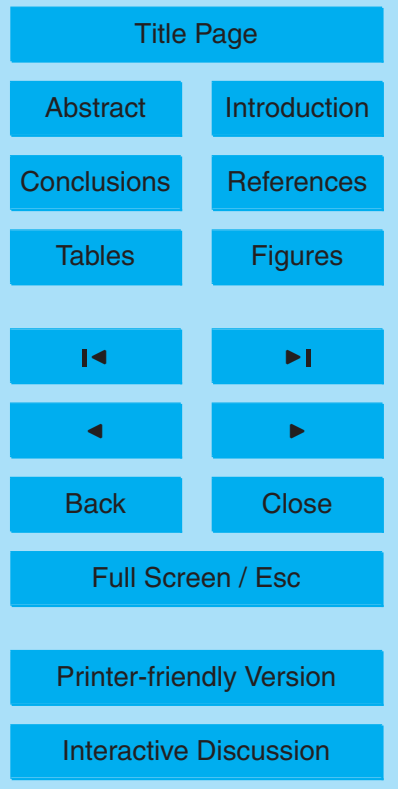


signature of a high correlation between anthropogenic halocarbons and $\mathrm{CO}$ observed near the NYC source region was retained in the samples taken within the plume layer over the GOM on 21 and 22 July. The $\mathrm{CH}_{2} \mathrm{Cl}_{2}-\mathrm{CO}$ and $\mathrm{C}_{2} \mathrm{Cl}_{4}-\mathrm{CO}$, and $\mathrm{C}_{2} \mathrm{HCl}_{3}-\mathrm{CO}$ correlations remained nearly unchanged on 21 July, each exceeding 0.9 at the $95 \%$ confidence level and facilitated tracking the plume while over the GOM region. Additional correlations determined between ethyne, propane, butane, benzene were similarly high, within a range of 0.8 to 0.9 with the same confidence interval. Yet, while the signature of the NYC plume was clear in the WASs as it entered the GOM, aircraft intercepts made on 21 July revealed that the plume structure continued to evolve sig10 nificantly during the preceding $24 \mathrm{~h}$ of its continued transit, with distinct differences in its characteristics over the coastal GOM versus the open North Atlantic.

Despite coalescing to one-quarter its near-source region thickness, enhancements in the primary species' mixing ratios still distinguished the plume layer between the surface and $500 \mathrm{~m}$ over the coastal GOM, as CO levels peaked in the coastal region at $15246 \mathrm{ppbv}, \mathrm{O}_{3}$ at $83 \mathrm{ppbv}, \mathrm{SO}_{2}$ at $4.2 \mathrm{ppbv}, \mathrm{HNO}_{3}$ at $5.8 \mathrm{ppbv}$, and benzene at $109 \mathrm{pptv}$ (Fig. 6a-d, red lines). A subsequent profile made 5 hours later to the northeast revealed the full lateral expanse of the plume as well as significant differences in its characteristics farther out to sea. As seen in Fig. 6e-h (red lines), peak mixing ratios in the primary species over the open North Atlantic were similar to those observed nearer the coast, as $\mathrm{CO}$ reached $337 \mathrm{ppbv}, \mathrm{O}_{3} 103 \mathrm{ppbv}, \mathrm{SO}_{2} 7.2 \mathrm{ppbv}$, and $\mathrm{HNO}_{3} 12.9 \mathrm{ppbv}$. This difference appeared to be linked to reduced cooling (i.e. slightly warmer temperatures) of the plume layer further out to sea as well as the presence of more vigorous turbulent motion indicated by the larger amplitudes (roughly $2 \times$ ) of TKE (Fig. $7 \mathrm{k}$, red lines).

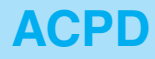

$12,2395-2434,2012$

\section{Transport and outflow to the North Atlantic during ICARTT 2004}

S. R. Davis et al.

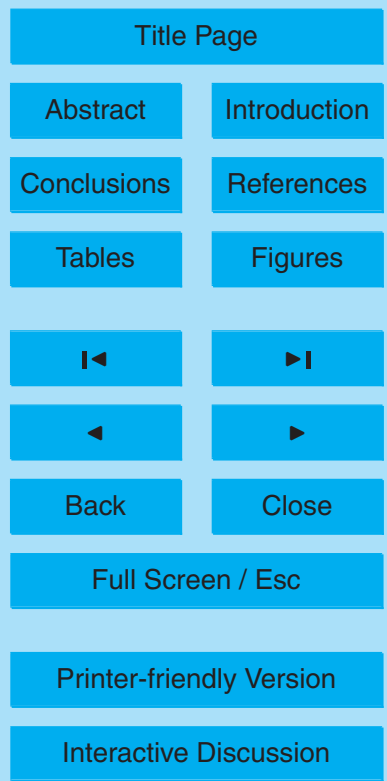


Turbulent characteristics remained apparent throughout the majority of the vertical profiles over the GOM with $R_{i}$ values persisting well below the 0.25 (Fig. $7 \mathrm{f}$ and I, red lines) indicative of instances of dynamic instability. $A \sim 130 \mathrm{~J} \mathrm{~kg}^{-1}$ intensification in TKE (Fig. 7k, red line) was evident throughout the plume layer in much the same way 5 that was observed near the source region; However, with the subsidence of the plume to a near surface altitude, the plume layer more closely resembled a coastal internal boundary layer (IBL) over the GOM than the residual layer encountered over NYC.

Internal boundary layers are frequently generated in the lower atmosphere and arise primarily from discontinuities in surface properties. In the case of the marine atmo10 sphere, coastal IBL's result from air masses advected across the coastline, where large differences in surface roughness and surface buoyancy (heat and moisture) fluxes are present on either side. In the case of the NYC plume, warm continental air trapped above the convective boundary layer in a residual layer was eventually advected into the lower marine troposphere. A resulting IBL formed based on significant differences 15 in airmass between the plume and its new marine environment. This scenario was recently addressed by Dacre et al. (2007) while coastal IBL transport has also been identified as a key aspect of regional transport, particularly over the GOM (Angevine et al., 1996; Smedman et al., 1997; Gong et al., 2000; Angevine et al., 2006).

A unique quality of this study was the Lagrangian observation of the plume with re20 spect to the development of an IBL structure and the resulting impacts on trace gas processing and transport. In terms of physical characteristics, horizontal transects made by the P3 on 21 and 22 July observed that many properties of the plume layer/IBL were remarkably constant over extensive distances across the GOM. As shown in Fig. 8a-b (cyan lines), wind speed and potential temperature each exhibited smooth gradients ond $160 \mathrm{~km}$ transect performed to the northeast along the GOM-open North Atlantic transition region provided observations that similar structure persisted further out to sea (Fig. 8a-b, magenta lines). In each case, winds within the IBL/plume layer were consistently southwesterly, ranging from 2 to $5 \mathrm{~m} \mathrm{~s}^{-1}$. Temperatures of the layer were

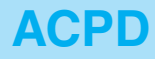

$12,2395-2434,2012$

\section{Transport and outflow to the North Atlantic during ICARTT 2004}

S. R. Davis et al.

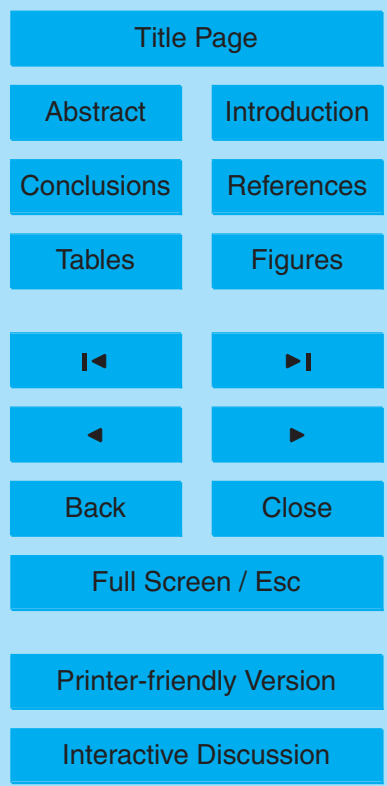


similar as well, with a mean of $297.2 \mathrm{~K}$, while the water vapor mixing ratio ranged from 10 to $14 \mathrm{~g} \mathrm{~kg}^{-1}$.

In contrast, trace gas observations made during the same transects exhibited high degrees of spatial variability and with two distinct regimes being apparent over the 5 coastal and open ocean waters. As shown in Fig. $9 \mathrm{a}-\mathrm{b}, \mathrm{O}_{3}$ and $\mathrm{CO}$ of the 20 July plume varied significantly, even over short spatial intervals. Within the same southern GOM transect discussed earlier, CO mixing ratios oscillated 160 ppbv about a mean value of $205 \mathrm{ppbv}$, and $\mathrm{O}_{3}$ ranged $\pm 70 \mathrm{ppbv}$ about a mean value of $117 \mathrm{ppbv}$ (cyan lines). Similar behavior was observed in $\mathrm{HNO}_{3}, \mathrm{SO}_{2}, \mathrm{MEK}$ and Benzene (Fig. 9c$10 \mathrm{f}$, cyan lines). In comparison, wide fluctuations in trace gas mixing ratios over the western GOM-open Atlantic suggested lower values but characterized similar behavior (magenta lines). Mixing ratios of $\mathrm{CO}$ were generally below 200 ppbv with $\mathrm{O}_{3}$ and $\mathrm{HNO}_{3}$ correspondingly less than 100 ppbv and 12 ppbv respectively.

The high degree of spatial heterogeneity in the mixing ratios appeared to be a direct 15 result to the persistent turbulence inherent to the IBL structure. Despite this near static appearance of the physical state of the plume layer observed on 21 July, frequent variations in vertical wind velocities (Fig. 8d, cyan and magenta lines) were recorded in each of the transects made in the plume as well as isolated spikes in TKE, indicating instances of turbulent activity. To some extent this was expected, with previous works firmly establishing that similar turbulent features and inherent characteristics of the growth of an IBL as a balance between the mixing of cool air by turbulence generated through shear driven TKE and an increase in the stable stratification due to buoyancy driven heat-loss to the surface is ultimately achieved (Garrett, 1987). As previously mentioned the impacts of an IBL on surface mixing ratios of $\mathrm{O}_{3}$ around the GOM has been explored in a number of works, yet none have captured the full magnitude and scale of the IBL-turbulence impact on a passing airmass' as seen in the aircraft observations of the 20 July plume.
ACPD

12, 2395-2434, 2012

\section{Transport and outflow to the North Atlantic during ICARTT 2004}

S. R. Davis et al.

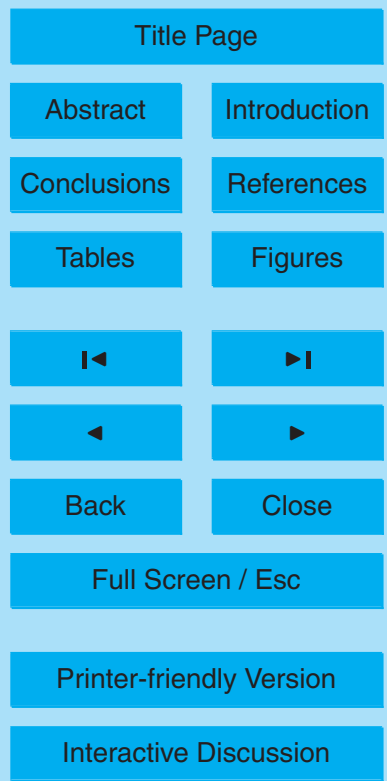




\subsection{2 (22 July Day 3)}

In the absence of new synoptic influences entering the GOM, the IBL-like structure surrounding the plume remained nearly constant throughout day 3 of the plume study. As seen in Fig. 8 (black lines), horizontal transects made within the plume layer on 22

5 July observed that the majority of its physical characteristics remained unchanged. As on 21 July, winds maintained a southwesterly flow (a mean $230^{\circ}$ in direction) within the layer, with the only exception being an average $2 \mathrm{~m} \mathrm{~s}^{-1}$ increase in wind speed on the 22 July. This increase contributed to increased vertical shear in wind speed within the plume and adjacent lower tropospheric layers, and facilitated the continued low $R_{i}$ 10 values (Fig. $7 f$ and I, green lines) well below the critical level, thus indicating frequent shear-driven turbulence and a higher probability of enhanced mixing on 22 July.

These conditions continued to have considerable impact on trace gas mixing ratios and chemical processing rates within the plume that day. As suggested in Mahrt et al. (1999) and Dacre et al. (2007), the overturning motion is pervasive throughout similar low altitude plumes/IBL layers and contributes significantly to the transit of the plume as well as mixing within it. On 22 July, this appeared to be realized as more concentrated elements of the plume arrived from upwind. Aircraft observations also provided evidence of mixing with recent emissions over the GOM, particularly in the coastal region. As seen in horizontal transects of the plume on 22 July (Fig. 9, black lines), the primary trace gas species retained their high spatial variability. On average, $20 \%$ higher mixing ratios were observed, as $\mathrm{CO}$ mixing ratios approached $400 \mathrm{ppbv}$ and $\mathrm{O}_{3}$ exceeded $100 \mathrm{ppbv}$. However, $\mathrm{NO}_{\mathrm{y}}$ remained relatively unchanged at $\sim 6 \mathrm{ppbv}$ with fresh emissions mixing into the plume and reduced deposition resulting from the detached nature of the plume's transit.

25 The third day of the plume study provided a unique cross-platform look at the plume with both the P3 and DC-8 intercepting it over the GOM. These encounters observed the trace gas enhancements clearly in relation to the plume's vertical structure. Profiles by the DC-8 over the western GOM on 22 July are shown in Fig. 10, and compared

\section{Transport and outflow to the North Atlantic during ICARTT 2004}

S. R. Davis et al.

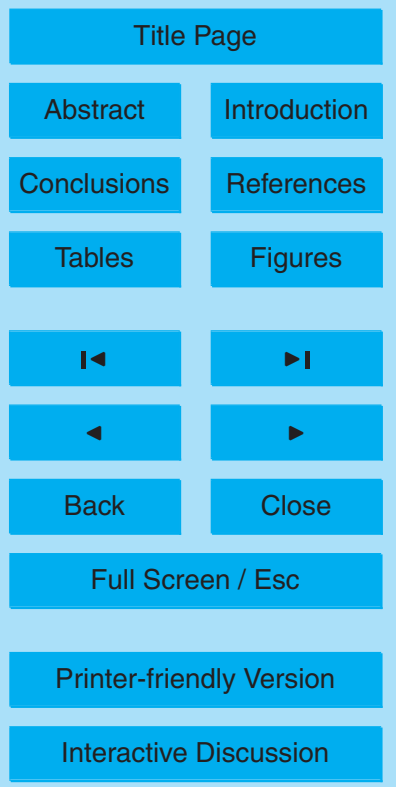


closely with the corresponding profiles by the P-3 presented in Figs. 6 and 7 . The vertical distribution of the halocarbon species used in tracking the plume was further seen in the DC-8 observations as well. Particularly evident were the enhancements in

$\mathrm{CHCl}_{3}$ (16pptv), $\mathrm{CH}_{3} \mathrm{CCl}_{3}$ (24 pptv), $\mathrm{C}_{2} \mathrm{Cl}_{4}$ (23 pptv), and $\mathrm{CH}_{2} \mathrm{Cl}_{2}$ (52 pptv). However,

5 it should be noted that the apparent homogeneity of the mixing ratios reflects the nature of the species sampling method (i.e. canisters) with repeated values were recorded in the datasets between sampling intervals.

Much of the increase in key species mixing ratios resulted from processing within the plume and mixing with fresher emissions. In particular, the enhancement in ozone 10 mixing ratios appeared to be a function of the sustained reduction in $\mathrm{O}_{3}$ loss facilitated by the IBL structure. As seen in Fig. 5, the plume $\mathrm{O}_{3} / \mathrm{CO}$ ratios increased substantially from their source region values on 20 July and particularly on 21 July where the $\mathrm{O}_{3} / \mathrm{CO}$ ratios exhibited best fitted slopes of 0.38 and 0.41 respectively. While these slopes were constant over the coastal waters on both days, a decrease from 0.41 to 0.34 15 was observed farther out to sea. This difference was one indication that lateral mixing may have occurred between the plume and local airmasses over the coastal region between 21 and 22 July. This was further suggested from significant changes in the $\mathrm{O}_{3} / \mathrm{NO}_{\mathrm{y}}$ ratios which, over the same period, showed a significant rise over the coastal region and a substantial decrease towards the open ocean.

\subsection{Inland and trans-atlantic impacts of NYC plume}

The initial impact of the plumes passage was observed on surface conditions around New England and evolved over the course of 3 days (21-23 July) as seen in the times series of trace gas observations made at the three AIRMAP stations (Fig. 11). As shown, initial detection was made along the coast, where the plume arrived at AIS 25

(green lines) and TFR (red lines) in a sequence of significant elevations in mixing ratios between 21 and 22 July. The first of these was sharp rise to $88 \mathrm{ppbv}$ in $\mathrm{O}_{3}$ at AIS between 18:00 UTC on 20 July and 06:00 UTC on 21 July with a coincident elevation to $63 \mathrm{ppbv}$ at TFR. These were accompanied over the same interval by a similar

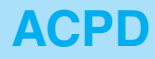

$12,2395-2434,2012$

\section{Transport and outflow to the North Atlantic during ICARTT 2004}

S. R. Davis et al.

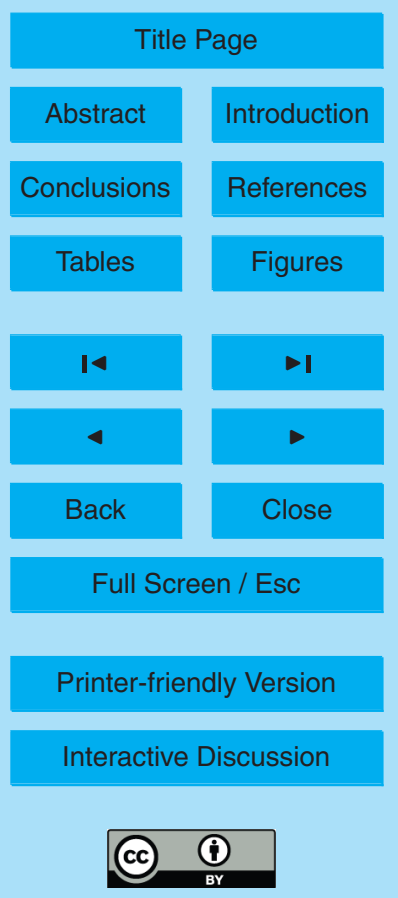


enhancement of the CO mixing ratios, reaching $190 \mathrm{ppbv}$ and $280 \mathrm{ppbv}$ at AIS and TFR respectively. Analysis of hourly canister observations at AIS and TFR showed enhancements coincided with elevations in halocarbon species used to track the NYC plume (Fig. 11c and d). These observations further captured an oscillating pattern 5 of mixing ratio increases with the arrival of the plume as indicated by higher levels of halocarbons at TFR than AIS as seen in Fig. 11c. This may be derived from increased mixing experienced by the plume as it progressed inland. Such phenomena has been observed between AIS and TFR during the New England Air Quality Study (NEAQS) of 2002 (Darby et al., 2006) as well as in the investigation of extreme ozone episodes 10 in the summer of 2001 (Mao and Talbot, 2004a).

Further inland, a lag of 3-6 $\mathrm{h}$ in the detection of the plume was observed at CSP. The inland arrival of $\mathrm{CO}$ from the plume manifested as monotonic increase until the morning of the 22 July when levels at CSP peaked at $395 \mathrm{ppbv}$. Ozone at the CSP showed a similar phase lag with the coastal observations, while the influence of the plume on the observed $\mathrm{O}_{3}$ mixing ratios at CSP was seen as a significant enhancement in its diurnal cycle. $\mathrm{O}_{3}$ mixing ratios observed at 12:00 UTC on 22 July at CSP equaled the highest observed that summer, representing the regional impact of the plume. During the plume's passage, CO mixing ratios at AIS, TFR, and CSP exceeded the 90th percentile of levels measured between 1 May 2004 and 1 September 2004. This was also the case for the observations of $\mathrm{O}_{3}$ and $\mathrm{SO}_{2}$.

One remarkable aspect of the 20 July NYC plume, was not only the quasi-lagrangian manner in which it was observed between NYC and the GOM, but also that its transit and impact were eventually measured over the United Kingdom. Upon leaving the GOM, forward trajectories computed by the HYSPLIT model indicated its continued flow along a southwesterly course across Nova Scotia, Newfoundland as seen in Fig. 12. By 25 July, these model trajectories tracked the plume to the west coast of Ireland and the British Isles, all while transiting within the lower marine troposphere. This trajectory and timeline was confirmed by intercepts of the plume of the western UK on 25 July, as detailed in Real et al. (2007). Further analysis of the plumes transit

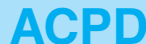

12, 2395-2434, 2012

\section{Transport and outflow to the North Atlantic during ICARTT 2004}

S. R. Davis et al.

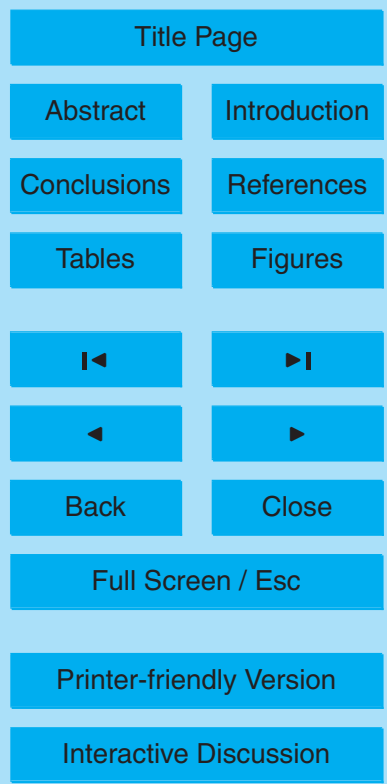


within the lower marine troposphere was also explored in this work, with the aid of the UKMet's lagrangian model analysis as detailed in Metven et al., 2006.

This low level means of outflow achieved by the 20 July plume study raises significant questions as to the frequency and impact of similar plumes across the Atlantic achieved

5 in the lower marine troposphere. While the 20 July plume was an extreme case within the context of ICARTT 2004, many similar transport events were observed during the course of the campaign. The dates and observed maxima in $\mathrm{CO}$ and $\mathrm{O}_{3}$ mixing ratios recorded within additional low level plumes intercepted over the GOM between 15 July and 7 August are indicated in Fig. 12c. Figure 12a and b present the HYSPLIT model 10 forward trajectories for these added encounters, suggesting the possible frequency of 20 July-like plume/outflow events occurring that summer.

\section{Summary and conclusions}

In this work, focus has been devoted to a distinct case of LLO that was observed in the GOM region by airborne and surface platforms beginning on 20 July 2004 . This event 15 was triggered by weak synoptic forcing, and was initially seen as a plume of concentrated industrial and urban pollution vented into shallow tropospheric layers above LIS. In a quasi-Lagrangian manner, multiple intercepts of the plume by the NOAA P-3 were made on subsequent days enabling it to be tracked during transit over the GOM and open western Atlantic waters.

20 Over the course of a three day quasi-Lagrangian experiment, the 20 July plume was seen to evolve, with clear linear correlations developing between signature species $\mathrm{CO}, \mathrm{O}_{3}$ and $\mathrm{NO}_{\mathrm{y}}$. More specifically, $\mathrm{O}_{3} / \mathrm{CO}$ relationships were consistently indicative of efficient photochemical production of $\mathrm{O}_{3} \cdot \mathrm{O}_{3} / \mathrm{NO}_{y}$ relationships near the source region showed signs of fresh emissions mixed with photochemically aged air. As the plume arrived in the designated coastal and outflow regions on 21 and 22 July, only the signature of fresh emissions was retained. The close correlation of $\mathrm{CO} / \mathrm{NO}_{\mathrm{y}}$ contributes to the argument that the plume experienced minimal interaction with the surface over

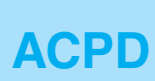

12, 2395-2434, 2012

\section{Transport and outflow to the North Atlantic during ICARTT 2004}

S. R. Davis et al.

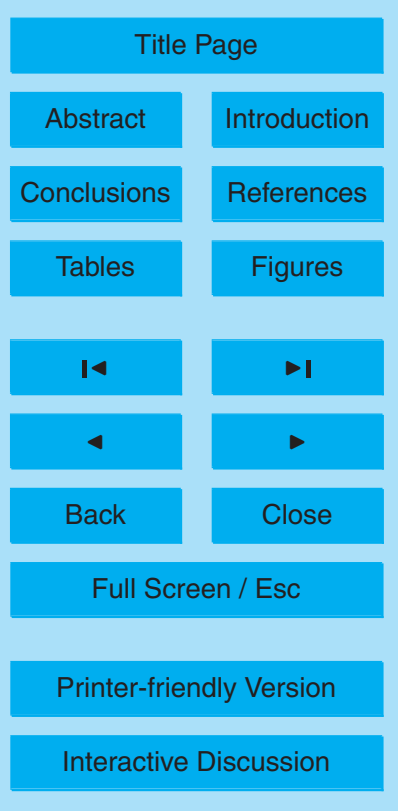


the course of its transit into the GOM and western Atlantic. Much of this detached transit was facilitated by SIBL-like properties of the plume containing layer.

The observation of SIBL-like properties in association with the plume layer in both the coastal and outflow regions is a unique finding that explains much of the efficiency 5 of the 20 July plumes transport and its eventual impact around the GOM and across the North Atlantic Ocean. On both days of the plume's transit across the GOM, the SIBL structure facilitated widespread observations of periodic turbulence with the plume layer. This turbulence appeared to drive the high levels of spatial heterogeneity in trace gas mixing ratios observed in the plume layer. Future studies which are fortunate 10 to gather similar Lagrangian data from a transiting plume within an IBL would benefit with micrometeorological measurements more capable of resolving the fine spatial scales of the inherent turbulent structures within them. Such observations would also facilitate analysis of other features that also influence low-level transport in the marine atmosphere in conjunction with SIBL's, including low level coastal jets, internal grav15 ity waves and turbulent eddies. Thus, the observations of the 20 July plume further motivate efforts to better understand the complex lower atmospheric influences that facilitate and shape plume transport over extended distances.

Acknowledgements. Financial support for this work was from the NOAA Office of Oceanic and Atmospheric Research under grant \#NA07OAR4600514. We thank the NASA and NOAA in20 vestigators on the DC-8 and P3-B aircrafts for use of their high quality data sets.

\section{References}

Angevine, W. M., Trainer, M., McKeen, S. A., and Berkowitz, C. M.: Meteorology of the New England coast, Gulf of Maine, and Nova Scotia: Overview, J. Geophys. Res., 101, 2889328901, 1996a.

25 Angevine, W. M., Buhr, M. P., Holloway, J. S., Trainer, M., Parrish, D., MacPherson, J. I., Kok, G. L., Dchillawski, R. D., Bowlby, D. H.: Local meteorological features affecting chemical measurements at a North Atlantic coastal site, J. Geophys. Res., 101, 28935-28946, 1996b.

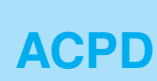

12, 2395-2434, 2012

\section{Transport and outflow to the North Atlantic during ICARTT 2004}

S. R. Davis et al.

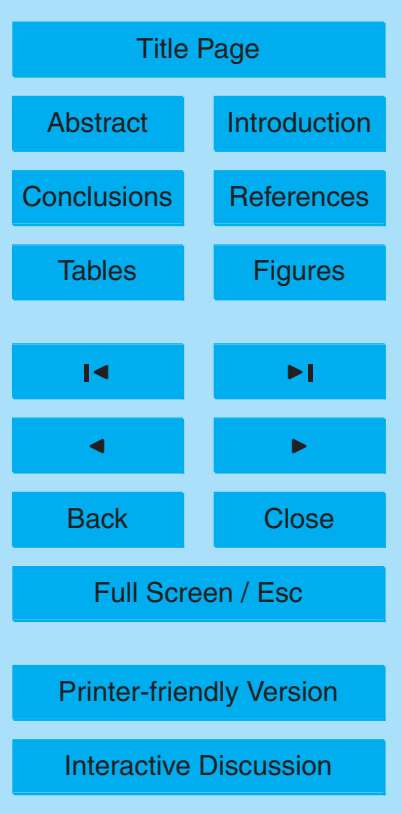


Angevine, W. M., Hare, J. E., Fairall, C. W. , Wolfe, D. E. , Hill, R. J. , Brewer, W. A., and White, A. B.: Structure and formation of the highly stable marine boundary layer over the Gulf of Maine, J. Geophys. Res., 111, D23S22, doi:10.1029/2006JD007465, 2006.

Angevine, W. M., Senff, C. J., White, A. B., Williams, E. J., Koermer, J., Miller, S. T. K., Talbot, $5 \quad$ R., Johnston, P. E., McKeen, S. A., and Downs, T.: Coastal boundary layer influence on pollutant transport in New England, J. Appl. Meteorol., 43, 1425-1437, 2004.

Chen, M., Talbot, R., Mao, H., Sive, B., Chen, J., and Griffin, R. J.: Air mass classification in coastal New England and its relationship to meteorological conditions, J. Geophys. Res., 112, D10S05, doi:10.1029/2006JD007687, 2007.

10 Chin, M., Jacob, D. J., Munger, J. W., Parrish, D. D., and Doddridge, B. G.: Relationship of ozone and carbon monoxide over North America, J. Geophys. Res., 99, 14565-14573, 1994.

Dacre, H. F., Gray, S. L., and Belcher, S. E.:, A case study of boundary layer ventilation by convection and coastal processes, J. Geophys. Res., 112, D17106, doi:10.1029/2006JD007984, 2007.

Darby, L. S., McKeen, S. A., Senff, C. J., White, A. B., Banta, R. M., Post, M. J., Brewer, W. A., Marchbanks, R., Alvarez II, R. J., Peckham, S. E., Mao, H., and Talbot, R.: Ozone differences between near-coastal and offshore sites in New England: Role of meteorology, J. Geophys. Res., 112, D16S91, doi:10.1029/2007JD008446, 2007.

Daum, P. H., Kleinman, L. I., Newman, L., Luke, W. T., Weinstein-Lloyd, J., Berkowitz, C. M., and Busness, K. M.: Chemical and physical properties of plumes of anthropogenic pollutants transported over the North Atlantic during the North Atlantic Regional Experiment, J.Geophys. Res., 101, 29029-29042, doi:10.1029/95JD03163, 1996.

Fairall, C. W., Bariteau, L., Grachev, A. A., Hill, R. J., Wolfe, D. E., Brewer, W. A., Tucker, S. C., Hare, J. E., and Angevine,W. M.: Turbulent bulk transfer coef?cients and ozone deposition velocity in the International Consortium for AtmosphericResearch into Transport and Transformation, J. Geophys. Res., 111, D23S20, doi:10.1029/2006JD007597, 2006.

Fehsenfeld, F. C., Daum, P., Leaitch, W. R., Trainer, M., Parrish, D. D., and Hübler, G.: Transport and processing of $\mathrm{O}_{3}$ and $\mathrm{O}_{3}$ precursors over the North Atlantic: An overview of the 1993 North Atlantic Regional Experiment (NARE) summer Intensive, J. Geophys. Res., 101, 28877-28891, 1996.

Fehsenfeld, F. C., Ancellet, G., Bates, T. S., Goldstein, A. H., Hardesty, R. M., Honrath, R., Law, K. S., Lewis, A. C., Leaitch, R., McKeen, S., Meagher, J., Parrish, D. D., Pszenny, A.

\section{Transport and outflow to the North Atlantic during ICARTT 2004}

S. R. Davis et al.

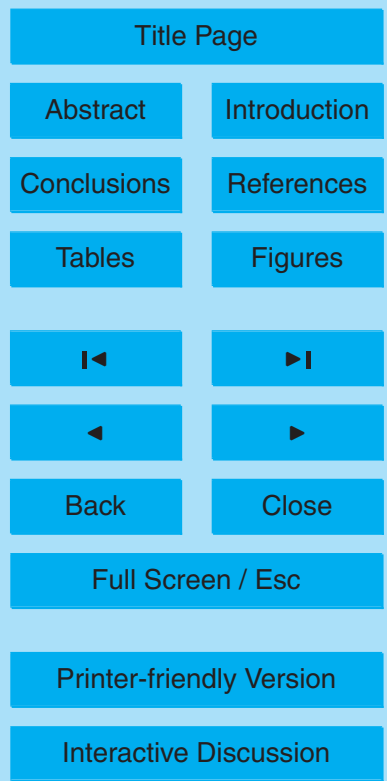


A. P., Russell, P. B., Schlager, H., Seinfeld, J., Talbot, R., and Zbinden, R.: International Consortium for Atmospheric Research on Transport and Transformation (ICARTT): North America to Europe - Overview of the 2004 summer field study, J. Geophys. Res., 111, D23S01, doi:10.1029/2006JD007829, 2006.

5 Garratt, J. R.: The stably stratified internal boundary-layer for steady and diurnally varying offshore flow, Bound. Layer Meteorol., 38, 369-394, 1987.

Garratt, J. R.: The internal boundary-layer - A review, Bound. Layer Meteorol., 50, 171-203, 1990.

Garratt, J. R. and Ryan, B. F.: The Structure of the Stably Stratified Internal Boundary Layer in

Gong, W., Mickle, R. E., Bottenheim, Foude, F., Beauchamp, S., and Waugh, D.: Marine/coastal boundary layer and vertical structure of ozone observed at a coastal site in Nova Scotia during the 1996 NARSTO-CE field campaign, Atmos. Environ., 34, 4139-4154, 2000.

Honrath, R. E., Owen, R. C., Martin, M. V., Reid, J. S., Lapina, K., Fialho, P., Dziobak, M. P., Kleissl, J., and Westphal, D. L.: Regional and hemispheric impacts of anthropogenic and biomass burning emissions on summertime $\mathrm{CO}$ and $\mathrm{O} 3$ in the North Atlantic lower free troposphere, J. Geophys. Res., 109, D24310, doi:10.1029/2004JD005147, 2004.

Hsu, S.-A.: Coastal Meteorology.International Geophysics Series Academic Press, New York, 260 pp., 1988.

20 Kleinman, L. I., Springston, S. R., Daum, P. H., Lee, Y.-N., Nunnermacker, L. J., Senum, G. I., Wang, J., Weinstein-Lloyd, J.,Alexander, M. L., Hubbe, J., Ortega, J., Canagaratna, M. R., and Jayne, J.: The time evolution of aerosol composition over the Mexico City plateau, Atmos. Chem. Phys., 8, 1559-1575, doi:10.5194/acp-8-1559-2008, 2008.

Kundu, P. K and Cohen, I. M.: Fluid Mechanics, Second Edition, Academic Press, San Diego, CA, USA, 730 pp., 1990.

Li, Q., Jacob, D. J., Bey, I., Palmer, P. I., Duncan, B. N., Field, B. D., Martin, R. V., Fiore, A. M., 20 Yantosca,, R. M., Parrish, D. D., Simmonds, P. G., and Oltmans, S. J.: Transatlantic transportof pollution and its effects on surface ozone in Europe and North America, J. Geophys. Res., 107, 4166, doi:10.1029/2001JD001422, 2002.

so Li, Q., Jacob, D. J., Park, R., Wang, Y., Heald, C. L., Hudman, R., Yantosca, R. M., Martin, R. V., and Evans, M.: North American pollution out?ow and the trapping of convectively lifted pollution by upper-level anticyclone, J. Goephys. Res., 110, D10301, doi:10.1029/2004JD005039, 2005.

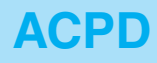

12, 2395-2434, 2012

\section{Transport and outflow to the North Atlantic during ICARTT 2004}

S. R. Davis et al.

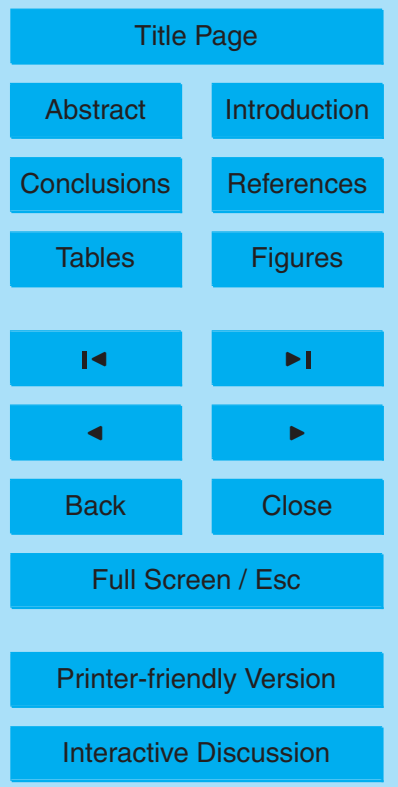


Mahrt, L.: Vertical Structure and Turbulence in the Very Stable Boundary Layer, J. Atmos. Sci. 42, 2333-2349, 1985.

Mao, $\mathrm{H}$. and Talbot, R.: Relationship of surface $\mathrm{O}_{3}$ to large-scale circulation patterns during two recent winters, Geophys. Res. Lett., 31, L06108, 10.1029/2003GL018860, 2004a.

$5 \mathrm{Mao}, \mathrm{H}$. and Talbot, R.:, $\mathrm{O}_{3}$ and $\mathrm{CO}$ in New England: Temporal variations and relationships, J. Geophys. Res., 109, D21304, doi:10.1029/2004JD004913, 2004 b.

Mao, H., Talbot, R., Troop, D., Johnson, R., Businger, S., and Thompson, A. M.: Smart balloon observations over the North Atlantic: O3 data analysis and modeling, J. Geophys. Res., 111, D23S56, doi:10.1029/2005JD006507, 2006.

10 Methven, J., Arnold, S. R., Stohl, A., Avery, M., Law, K., Lewis, A., Parrish, D., Reeves, C., Schlager, H., Atlas, E., Blake, D., and Rappengluck, B.: Establishing Lagrangian connections between observations within air masses crossing the Atlantic during the ICARTT experiment, J. Geophys. Res., 111, D23S62, doi:10.1029/2006JD007540, 2006.

Millet, D. B., Goldstein, A. H., Holzinger, R., Williams, B. J., Allan, J. D., Jimenez, J. L., Worsnop,

15 D. R., Roberts, J. M., White, A. B., Hudman, R. C., Bertschi, I. T., and Stohl, A.: Chemical characteristics of North American surface layer out?ow: Insights from Chebogue Point Nova Scotia, J. Geophys. Res., 111, D23S53, doi:10.1029/2006JD007287, 2006.

Neuman, J. A., Parrish, D. D., Trainer, M., Ryerson, T. B., Holloway, J. S., Nowak, J. B., Swanson, A., Flocke, F., Roberts, J. M., Brown, S. S., Stark, H., Sommariva, R., Stohl, A., Peltier, R., Weber, R., Wollny, A. G., Sueper, D. T., Hubler, G., and Fehsenfeld, F. C.: Reactive nitrogen transport and photochemistry in urban plumes over the North Atlantic Ocean, J. Geophys. Res., 111, D23S54, doi:10.1029/2005JD007010, 2006.

Owen, R. C., Cooper, O. R., Stohl, A., and Honrath, R. E.: An analysis of the mechanisms of North American pollutant transport to the central North Atlantic lower free troposphere., J. Geophys. Res., 111, D23S58, doi:10.1029/2006JD007062, 2006.

Parrish, D. D., Holloway, J. S., Trainer, M., Murphy, P. C., Forbes, G. L., and Fehsenfeld, F. C.: Export of North American Ozone Pollution to the North Atlantic Ocean, Science, 259, 1436-1439, 1993.

Real, E., Law, K. S., Schlager, H., Roiger, A., Huntrieser, H., Methven, J., Cain, M., Holloway, J., Neuman, J. A., Ryerson, T., Flocke, F., de Gouw, J., Atlas, E., Donnelly, S., and Parrish, D.: Lagrangian analysis of low altitude anthropogenic plume processing across the North Atlantic, Atmos. Chem. Phys., 8, 7737-7754, doi:10.5194/acp-8-7737-2008, 2008.

Simmonds, P. G., Derwent, R. G., Manning, A. L., and Spain,G.: Significant growth in surface

\section{Transport and outflow to the North Atlantic during ICARTT 2004}

S. R. Davis et al.

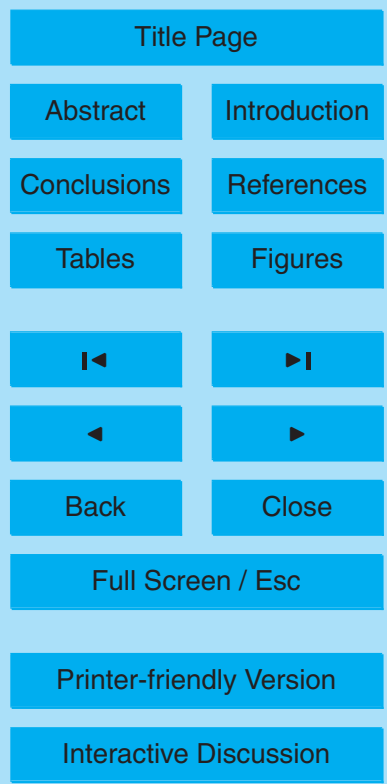


ozone at Mace Head, Ireland, 1987-2003, Atmos. Environ., 38, 4769-4778. 2003.

Slowik, J. G., Brook, J., Chang, R. Y.-W., Evans, G. J., Hayden, K., Jeong, C.-H., Li, S.-M., Liggio, J., Liu, P. S. K., McGuire, M., Mihele, C., Sjostedt, S., Vlasenko, A., and Abbatt, J. P. D.: Photochemical processing of organic aerosol at nearby continental sites: contrast between urban plumes and regional aerosol, Atmos. Chem. Phys., 11, 2991-3006, doi:10.5194/acp11-2991-2011, 2011.

Smedman, A.-S., Bergström, H., and Grisogono, B.: Evolution of stable internal boundary layers over a cold sea, J. Geophys. Res., 102, 1091-1099, doi:10.1029/96JC02782, 1997.

Stohl, A. and Trickl, T.: A textbook example of long-range transport: Simultaneous observation of ozone maxima of stratospheric and North American origin in the free troposphere over Europe, J. Geophys. Res., 104, 30445-30462, 1999.

Stull, R. B.: An Introduction to Boundary Layer Meteorology, Kluwer Academic, Dordrecht, The Netherlands, 683 pp., 1988.

Tardif, R. and Rasmussen, R. M.: Process-oriented analysis of environmental conditions as15 sociated with precipitation fog events in the New York City region. J. Appl. Meteor. Climatol. 005, 2007.

Trickl, T., Cooper, O. R., Eisele, H., James, P., Mucke, R., and Stohl, A.: Intercontinental transport and its influence on the ozone concentrations over central Europe: Three case studies, J. Geophys. Res., 108, 8530, doi:10.1029/2002JD002735, 2003.

\section{ACPD}

12, 2395-2434, 2012

\section{Transport and outflow to the North Atlantic during ICARTT 2004}

S. R. Davis et al.

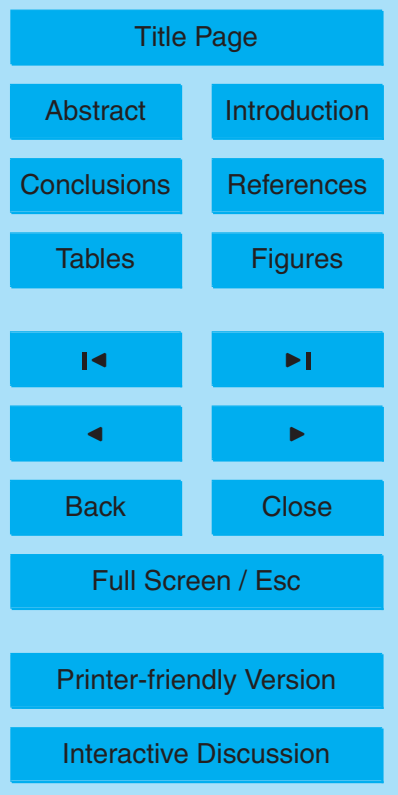


Table 1. Analysis of Whole Air Samples taken within the plume layer over NYC on 20 July as well as over the GOM on 21 and 22 July. Included are maximum and mean values for each species, and correlations with CO calculated to the $95 \%$ confidence level in each case.

\begin{tabular}{|c|c|c|c|c|c|c|c|c|c|}
\hline WAS Sample Species & 720 Corrleations & 720 maxes & 720 means & 721 Correlations & 721 maxes & 721 means & 722 Correlations & 722 maxes & 722 means \\
\hline CFC_11 & 0.964 & 289.700 & 262.927 & 0.769 & 270.700 & 260.800 & 0.685 & 58271.000 & 57070.000 \\
\hline CFC_12 & 0.936 & 581.900 & 555.109 & 0.856 & 557.800 & 550.280 & 0.837 & 58278.000 & 57078.000 \\
\hline CFC_113 & 0.929 & 83.300 & 81.136 & 0.236 & 82.000 & 81.300 & 0.143 & 259.200 & 254.230 \\
\hline CFC_114 & 0.564 & 15.170 & 14.747 & 0.219 & 14.690 & 14.587 & 0.099 & 549.800 & 544.670 \\
\hline CFC_115 & 0.637 & 7.360 & 6.857 & 0.432 & 7.290 & 6.950 & 0.395 & 80.400 & 79.917 \\
\hline HFC_134a & 0.972 & 227.400 & 95.018 & 0.916 & 105.500 & 76.917 & 0.442 & 14.630 & 14.488 \\
\hline HCFC_21 & 0.966 & 1.000 & 0.654 & 0.802 & 0.880 & 0.685 & 0.395 & 6.930 & 6.608 \\
\hline HCFC_22 & 0.924 & 756.600 & 313.627 & 0.733 & 324.300 & 259.330 & 0.661 & 63.300 & 52.317 \\
\hline HCFC_123 & 0.963 & 1.000 & 0.440 & 0.431 & 0.650 & 0.478 & 0.397 & 0.660 & 0.533 \\
\hline HCFC_124 & 0.560 & 11.100 & 3.452 & 0.652 & 4.040 & 2.560 & 0.666 & 224.800 & 201.600 \\
\hline HCFC_141b & 0.880 & 49.440 & 26.653 & 0.927 & 27.350 & 24.015 & 0.769 & 0.370 & 0.300 \\
\hline HCFC_142b & 0.965 & 41.560 & 26.164 & 0.962 & 30.670 & 24.983 & 0.528 & 1.950 & 1.573 \\
\hline $\mathrm{CH} 2 \mathrm{Cl} 2$ & 0.893 & 264.100 & 82.773 & 0.926 & 63.600 & 43.850 & 0.802 & 23.770 & 21.478 \\
\hline $\mathrm{CHCl} 3$ & 0.979 & 28.780 & 17.297 & 0.916 & 22.310 & 16.432 & 0.798 & 22.680 & 20.525 \\
\hline X1_2_dichloroethane & 0.859 & 5.370 & 4.762 & 0.731 & 4.440 & 4.263 & 0.354 & 39.700 & 30.483 \\
\hline $\mathrm{CH} 3 \mathrm{CCL} 3$ & 0.976 & 28.600 & 25.055 & 0.952 & 25.700 & 24.483 & 0.773 & 16.010 & 12.640 \\
\hline $\mathrm{CCl} 4$ & 0.550 & 98.000 & 96.091 & 0.167 & 98.000 & 96.333 & 0.162 & 4.900 & 4.398 \\
\hline $\mathrm{C} 2 \mathrm{Cl} 4$ & 0.950 & 188.000 & 49.360 & 0.962 & 40.200 & 18.047 & 0.762 & 25.000 & 24.100 \\
\hline $\mathrm{C} 2 \mathrm{HCl} 3$ & 0.859 & 28.000 & 8.945 & 0.953 & 5.800 & 3.022 & 0.697 & 96.000 & 95.667 \\
\hline Halon_1301 & 0.666 & 3.180 & 2.804 & 0.529 & 2.880 & 2.653 & 0.440 & 12.900 & 8.002 \\
\hline Halon_1211 & 0.953 & 6.020 & 4.744 & 0.907 & 4.850 & 4.510 & 0.704 & 1.400 & 0.853 \\
\hline Halon_2402 & 0.571 & 0.490 & 0.470 & 0.598 & 0.490 & 0.473 & 0.616 & 2.790 & 2.695 \\
\hline $\mathrm{CH} 3 \mathrm{Cl}$ & 0.447 & 531.000 & 516.000 & 0.105 & 537.000 & 521.170 & 0.203 & 4.560 & 4.358 \\
\hline $\mathrm{CH} 3 \mathrm{Br}$ & 0.613 & 10.600 & 9.375 & 0.193 & 11.400 & 10.050 & 0.319 & 0.470 & 0.450 \\
\hline $\mathrm{CH} 3 \mathrm{I}$ & 0.582 & 0.760 & 0.514 & 0.501 & 1.640 & 0.990 & 0.538 & 535.000 & 512.500 \\
\hline n_C $3 \mathrm{H} 7 \mathrm{Br}$ & 0.411 & 32.800 & 798.764 & 0.982 & 5.810 & 3.003 & 0.810 & 10.200 & 9.420 \\
\hline $\mathrm{CH} 2 \mathrm{Br} 2$ & 0.871 & 0.830 & 0.734 & 0.297 & 1.090 & 0.855 & 0.390 & 0.650 & 0.390 \\
\hline $\mathrm{CHClBr} 2$ & 0.948 & 0.320 & 0.170 & 0.664 & 0.360 & 0.222 & 0.518 & 1.800 & 1.310 \\
\hline $\mathrm{CHBr} 3$ & 0.856 & 1.160 & 0.740 & 0.306 & 2.910 & 1.562 & 0.197 & 0.720 & 0.667 \\
\hline ocs & 0.146 & 455.000 & 426.273 & 0.848 & 473.000 & 443.330 & 0.310 & 0.140 & 0.107 \\
\hline DMS & 0.410 & 15.510 & 803.595 & 0.434 & 0.390 & 0.240 & 0.478 & 0.960 & 0.480 \\
\hline MeONO2 & 0.995 & 5.470 & 3.526 & 0.434 & 0.390 & 0.240 & 0.478 & 0.960 & 0.480 \\
\hline EthONO2 & 0.919 & 6.560 & 4.276 & 0.868 & 7.480 & 5.205 & 0.715 & 1.310 & 0.635 \\
\hline i_C3ONO2 & 0.889 & 17.900 & 11.115 & 0.857 & 23.540 & 15.373 & 0.716 & 3.260 & 2.692 \\
\hline n_C3ONO2 & 0.950 & 2.500 & 1.414 & 0.853 & 2.780 & 1.795 & 0.728 & 4.720 & 3.417 \\
\hline X2_BuONO2 & 0.953 & 14.900 & 8.328 & 0.890 & 21.940 & 12.178 & 0.658 & 12.530 & 8.297 \\
\hline X3Me2BuONO2 & 0.966 & 4.570 & 2.350 & 0.940 & 5.830 & 2.688 & 0.726 & 1.340 & 0.938 \\
\hline X3_C5ONO2 & 0.930 & 5.610 & 2.926 & 0.912 & 7.580 & 3.968 & 0.778 & 8.320 & 5.563 \\
\hline X2_C5ONO2 & 0.956 & 7.820 & 3.886 & 0.923 & 10.020 & 4.848 & 0.771 & 1.750 & 0.928 \\
\hline ETHANE & 0.960 & 2840.000 & 1693.273 & 0.501 & 2423.000 & 1591.200 & 0.587 & 2.240 & 1.533 \\
\hline
\end{tabular}

12, 2395-2434, 2012

\section{Transport and outflow to the North Atlantic during ICARTT 2004}

S. R. Davis et al.

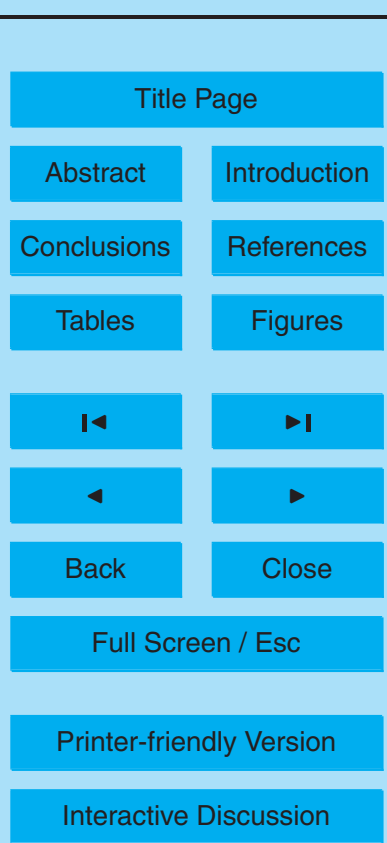


Table 1. Continued.

\begin{tabular}{|c|c|c|c|c|c|c|c|c|c|}
\hline WAS Sample Species & 720 Corrleations & 720 maxes & 720 means & 721 Correlations & 721 maxes & 721 means & 722 Correlations & 722 maxes & 722 means \\
\hline ETHYNE & 0.986 & 1062.400 & 472.036 & 0.954 & 493.900 & 313.680 & 0.824 & 2.350 & 1.568 \\
\hline ETHENE & 0.512 & 936.000 & 599.000 & 0.708 & 140.000 & 53.333 & 0.585 & 1917.000 & 1466.800 \\
\hline PROPANE_FID & 0.640 & 1642.000 & 252.364 & 0.884 & 1074.000 & 628.000 & 0.770 & 243.500 & 182.550 \\
\hline PROPENE & 0.519 & 144.000 & 1774.000 & 0.799 & 11.000 & 7.667 & 0.624 & 20.000 & 14.167 \\
\hline PROPANE_MSD & 0.956 & 1694.000 & 721.000 & 0.892 & 1029.000 & 620.670 & 0.774 & 383.000 & 272.830 \\
\hline I_BUTANE & 0.969 & 519.500 & 162.218 & 0.851 & 193.100 & 96.700 & 0.455 & 13.000 & 7.167 \\
\hline N_BUTANE & 0.974 & 670.500 & 225.755 & 0.964 & 255.100 & 122.180 & 0.781 & 374.000 & 269.170 \\
\hline I_PENTANE & 0.985 & 811.200 & 279.909 & 0.966 & 182.100 & 88.850 & 0.830 & 43.200 & 24.550 \\
\hline N_PENTANE & 0.980 & 338.300 & 111.945 & 0.965 & 87.000 & 43.150 & 0.827 & 48.300 & 33.900 \\
\hline ISOPRENE & 0.173 & 800.800 & 218.555 & 0.915 & 0.800 & 0.467 & 0.185 & 37.700 & 18.117 \\
\hline BENZENE & 0.980 & 268.200 & 108.745 & 0.905 & 111.000 & 69.617 & 0.823 & 17.200 & 9.517 \\
\hline TOLUENE & 0.964 & 797.800 & 230.209 & 0.781 & 120.400 & 43.600 & 0.756 & 1.700 & 0.583 \\
\hline Ethyl_benzene & 0.962 & 115.620 & 31.395 & 0.765 & 16.280 & 5.725 & 0.733 & 54.300 & 41.700 \\
\hline m_p_xylene & 0.942 & 210.100 & 50.275 & 0.555 & 10.120 & 3.085 & 0.470 & 8.000 & 3.650 \\
\hline o_xylene & 0.956 & 90.300 & 23.539 & 0.630 & 7.140 & 2.300 & 0.598 & 1.170 & 0.510 \\
\hline iso_propyl_benzene & 0.957 & 9.260 & 2.554 & 0.806 & 2.030 & 0.802 & 0.712 & 0.790 & 0.343 \\
\hline X2_ethyl_toluene & 0.930 & 34.190 & 8.078 & 0.589 & 2.150 & 0.808 & 0.581 & 0.700 & 0.368 \\
\hline X3_ethyl_toluene & 0.923 & 59.820 & 13.509 & 0.519 & 2.220 & 0.808 & 0.429 & 0.390 & 0.258 \\
\hline X4_ethyl_toluene & 0.931 & 35.280 & 8.193 & 0.559 & 1.930 & 0.643 & 0.580 & 0.660 & 0.322 \\
\hline X1_3_5_trimethyl_benzene & 0.834 & 6.200 & 1.433 & 0.175 & 0.370 & 0.273 & 0.226 & 0.820 & 0.393 \\
\hline X1_2_4_trimethyl_benzene & 0.910 & 44.990 & 10.253 & 0.498 & 1.440 & 1.013 & 0.140 & 0.420 & 0.207 \\
\hline X1_2_3_trimethyl_benzene & 0.904 & 11.690 & 2.963 & 0.563 & 0.580 & 0.477 & 0.139 & 0.320 & 0.160 \\
\hline a_pinene & 0.336 & 6.000 & 1.836 & 0.349 & 0.500 & 0.267 & 0.437 & 1.320 & 0.618 \\
\hline b_pinene & 0.318 & 4.200 & 1.736 & 0.486 & 1.900 & 0.617 & 0.317 & 1.150 & 0.435 \\
\hline d_limonene & 0.164 & 3.700 & 0.000 & 0.308 & 0.400 & 0.117 & 0.561 & 0.800 & 0.483 \\
\hline MTBE & 0.878 & 295.700 & 60.109 & 0.666 & 125.500 & 44.533 & 0.639 & 0.600 & 0.383 \\
\hline Methacrolein & 0.500 & 562.000 & 227.636 & 0.568 & 21.000 & 12.167 & 0.115 & 0.300 & 0.000 \\
\hline METHYLETHYL_KETONE & 0.404 & 1268.000 & 677.545 & 0.627 & 75.000 & 31.333 & 0.364 & 10.900 & 4.433 \\
\hline X2_BUTANONE & 0.895 & 980.000 & 445.545 & 0.885 & 571.000 & 406.670 & 0.706 & 23.000 & 12.333 \\
\hline X3_mefuran & 0.575 & 41.500 & 12.245 & 0.277 & 9.100 & 5.467 & 0.532 & 51.000 & 26.500 \\
\hline $\mathrm{CH} 4$ & 0.961 & 1950.000 & 1856.818 & 0.807 & 1904.000 & 1858.500 & 0.460 & 287.000 & 200.500 \\
\hline
\end{tabular}

\section{Transport and outflow to the North Atlantic during ICARTT 2004}

S. R. Davis et al.

Title Page

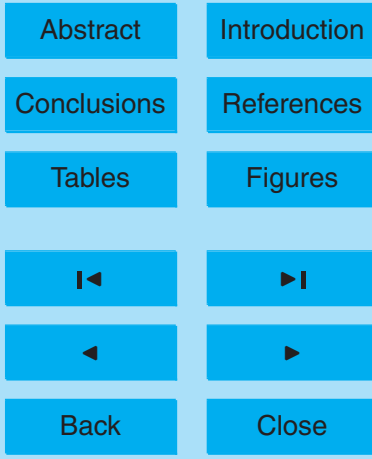

Full Screen / Esc

Printer-friendly Version

Interactive Discussion 

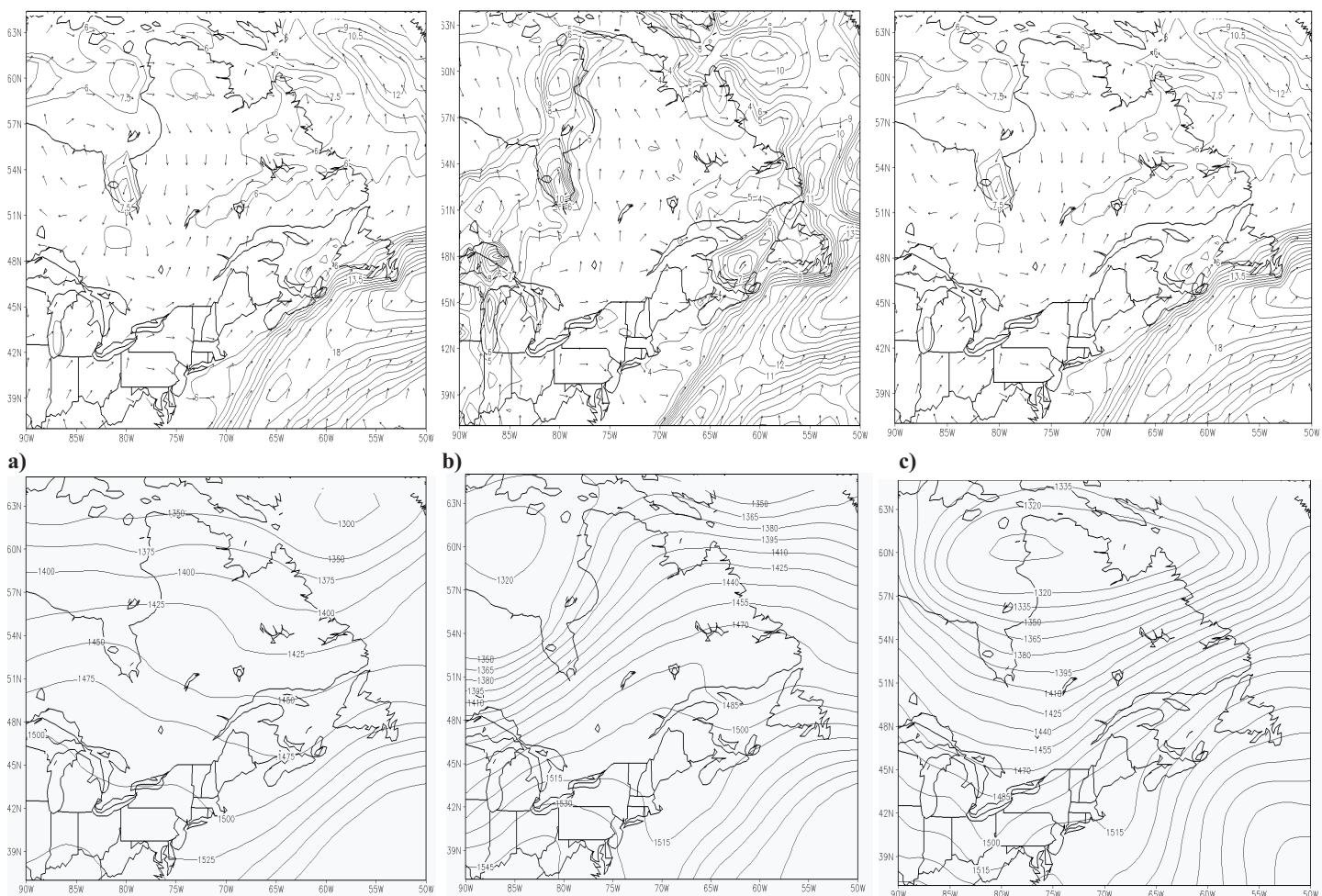

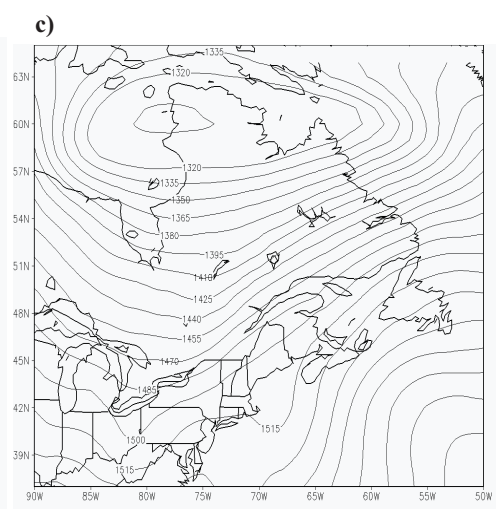

f)

Fig. 1. NCEP Reanalysis of mean sea level pressure and surface wind vectors for (a) 20 July, (b) 21 July and (c) 22 July during the 2004 ICARTT campaign. $850 \mathrm{mb}$ geopotential heights are shown for the same respective dates in (d), (e) and (f).

\section{ACPD}

$12,2395-2434,2012$

\section{Transport and outflow to the North Atlantic during ICARTT 2004}

S. R. Davis et al.

Title Page

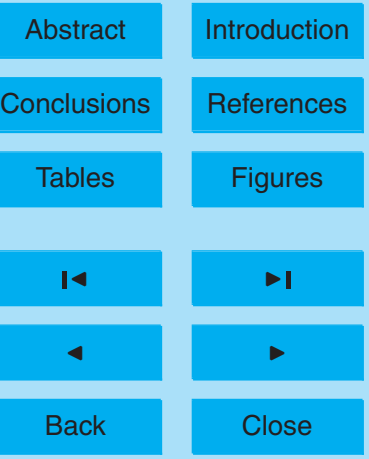

Full Screen / Esc

Printer-friendly Version

Interactive Discussion 


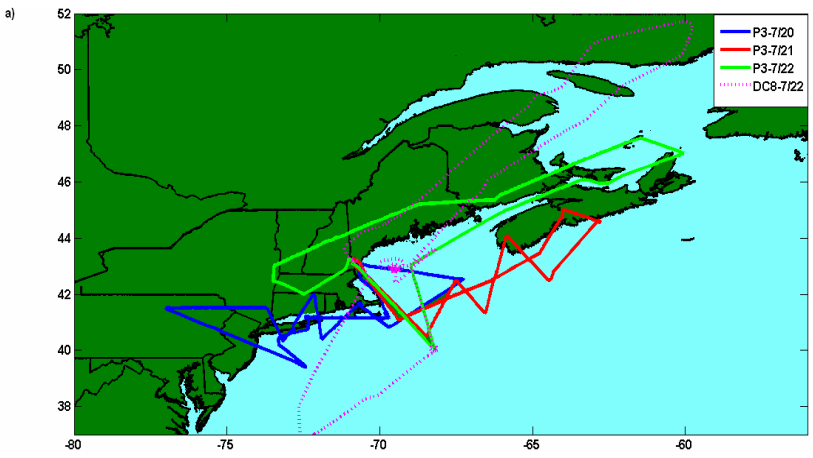

\section{ACPD}

12, 2395-2434, 2012

\section{Transport and outflow to the North Atlantic during ICARTT 2004}

S. R. Davis et al.

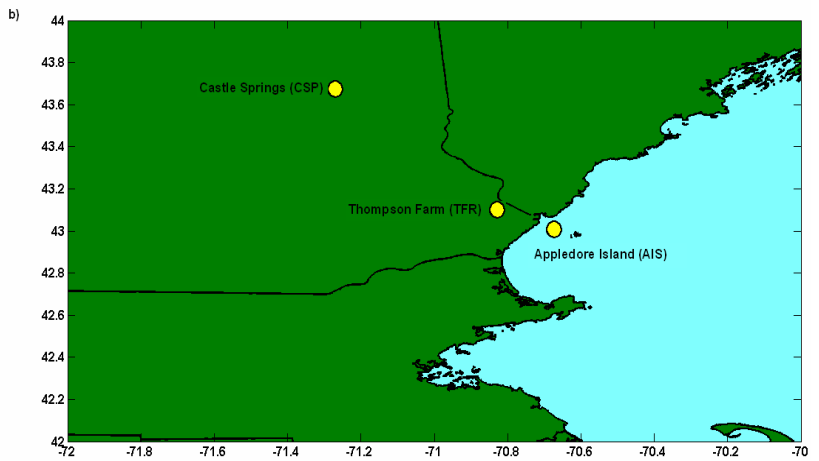

Title Page

Abstract

Conclusions

\section{Tables}

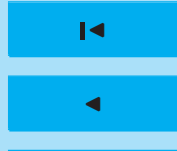

Back
Introduction

References

Figures

$\rightarrow 1$

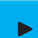

Close

Full Screen / Esc

Printer-friendly Version

Interactive Discussion 

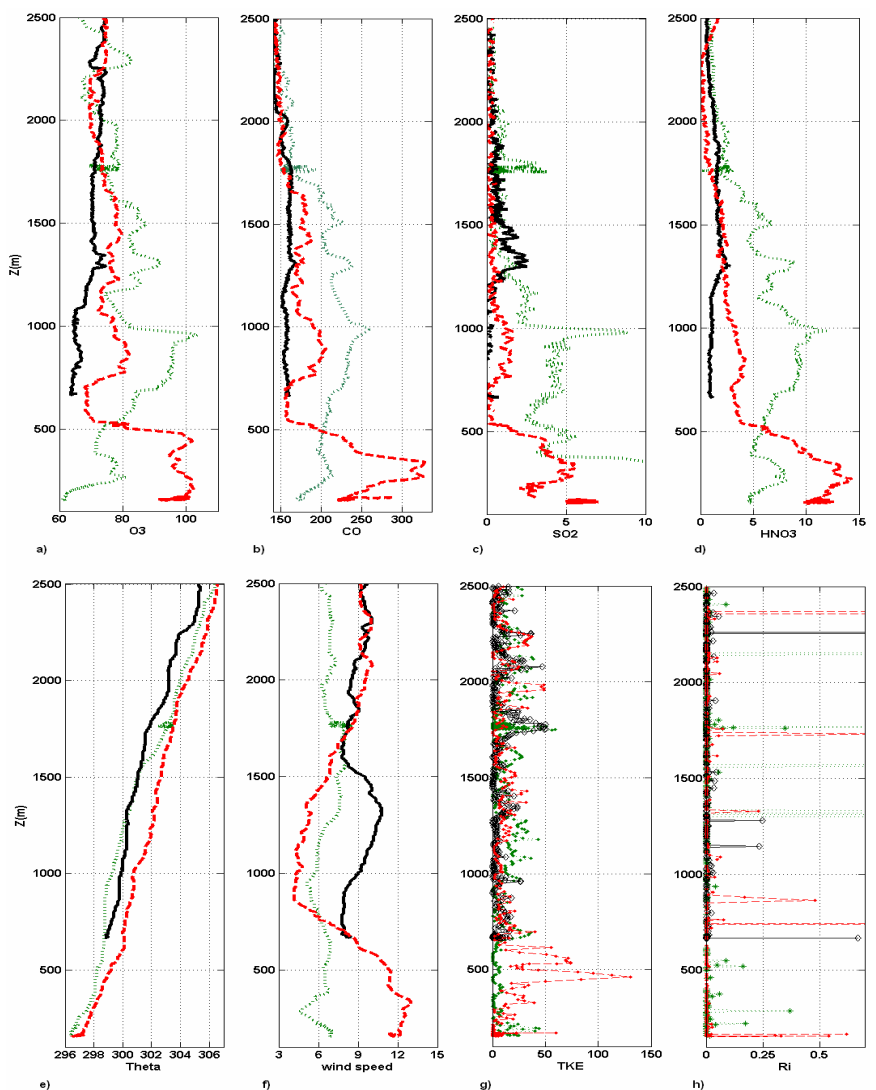
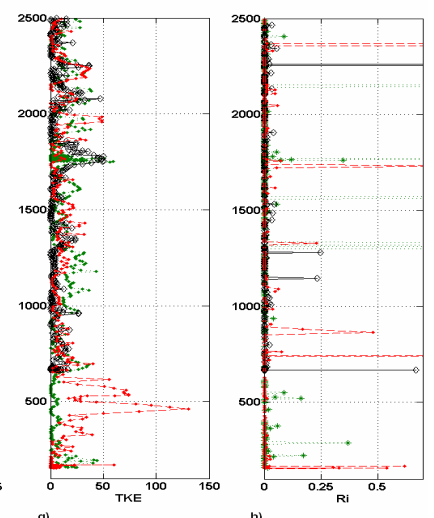

\section{ACPD}

12, 2395-2434, 2012

\section{Transport and outflow to the North Atlantic during ICARTT 2004}

S. R. Davis et al.

\section{Title Page}

\section{Abstract}

Introduction

Conclusions

References

Tables

Figures

14

Back

\section{Full Screen / Esc}

Printer-friendly Version

Interactive Discussion 

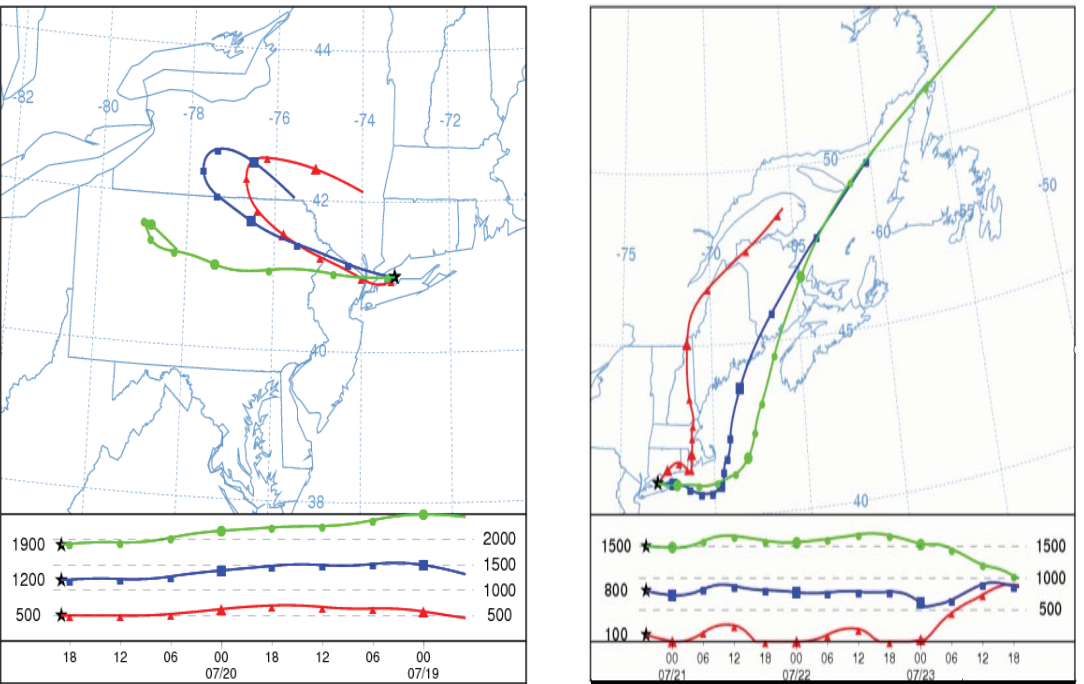

Fig. 4. NOAA HYSPLIT lagrangian model simulations showing the probable (a) back trajectories for two days prior to the initial encounter with the 20 July plume by the WP-3D and (b) forward trajectories for five days following the same encounter

$12,2395-2434,2012$

\section{Transport and outflow to the North Atlantic during ICARTT 2004}

S. R. Davis et al.

\section{Title Page}

\section{Abstract}

Introduction

Conclusions

References

Tables

Figures

14

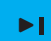

Back

Close

Full Screen / Esc

Printer-friendly Version

Interactive Discussion 

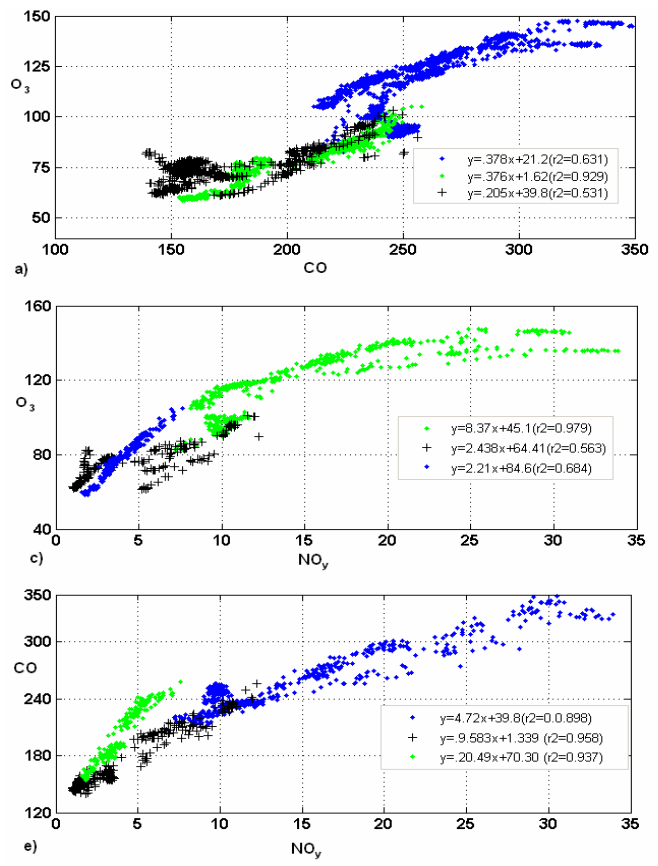

Fig. 5. Selected trace gas relationships with the plume layer and parameters for corresponding linear fits. Shown are $\mathrm{O}_{3} / \mathrm{NO}_{\mathrm{y}}, \mathrm{O}_{3} / \mathrm{NO}_{\mathrm{y}}$ and $\mathrm{CO} / \mathrm{NO}_{\mathrm{y}}$ for the coastal GOM P3 aircraft observations in (a), (c) and (e) respectively and for the open ocean observations in (b), (d) and (f). Black markers designate observations within the plume over the NYC source region on 20 July, blue markers designate observations over the GOM on 21 July and green markers designate observations over the GOM on 22 July with all values being in ppbv.

\section{ACPD}

12, 2395-2434, 2012

\section{Transport and outflow to the North Atlantic during ICARTT 2004}

S. R. Davis et al.

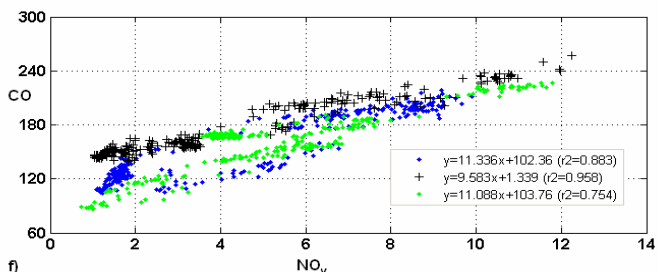

Title Page

Abstract

Introduction

Conclusions

References

Tables

Figures

14

$\rightarrow$

$<$

Back

Close

Full Screen / Esc

Printer-friendly Version

Interactive Discussion 

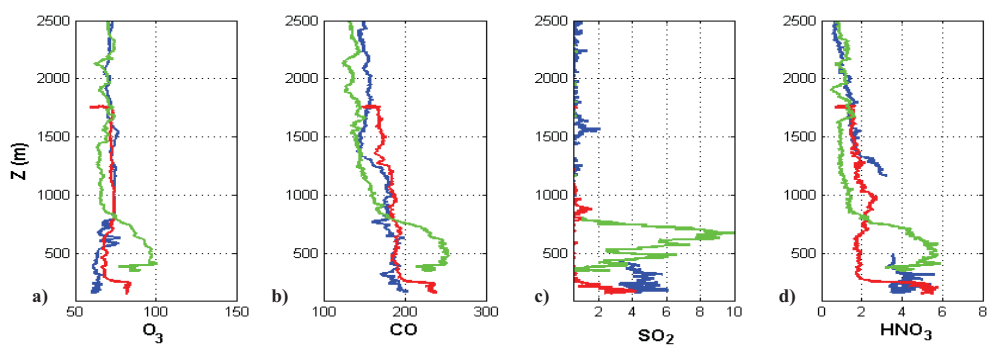

\section{ACPD}

12, 2395-2434, 2012
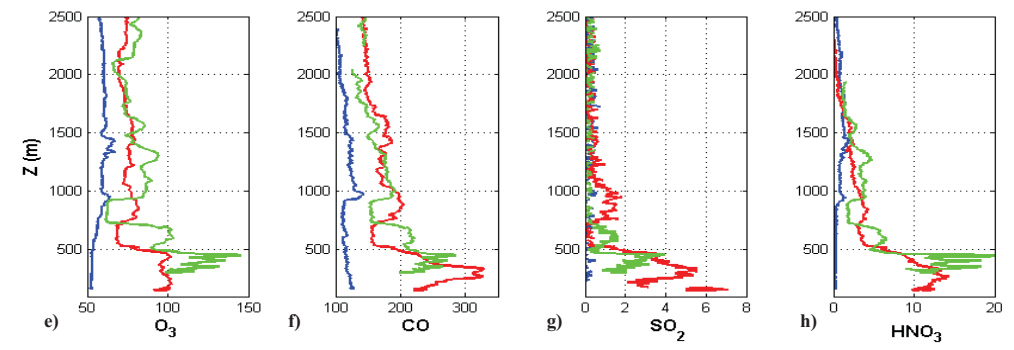

Fig. 6. Aircraft profiles over the coastal GOM of (a) $\mathrm{O}_{3}$, (b) $\mathrm{CO}$, (c) $\mathrm{SO}_{2}$ and (d) $\mathrm{HNO}_{3}$. Corresponding observations of the same trace gas species over the western Atlantic/ eastern GOM are shown in (e)-(h). Blue lines represent observations on 20 July, red 21 July and green 22 July with all trace gas observations made in ppbv.

\section{Transport and outflow to the North Atlantic during ICARTT 2004}

S. R. Davis et al.

\section{Title Page}

\section{Abstract}

Conclusions

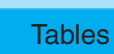

14

4

Back
Introduction

References

Figures

$\rightarrow$

Close

\section{Full Screen / Esc}

Printer-friendly Version

Interactive Discussion 

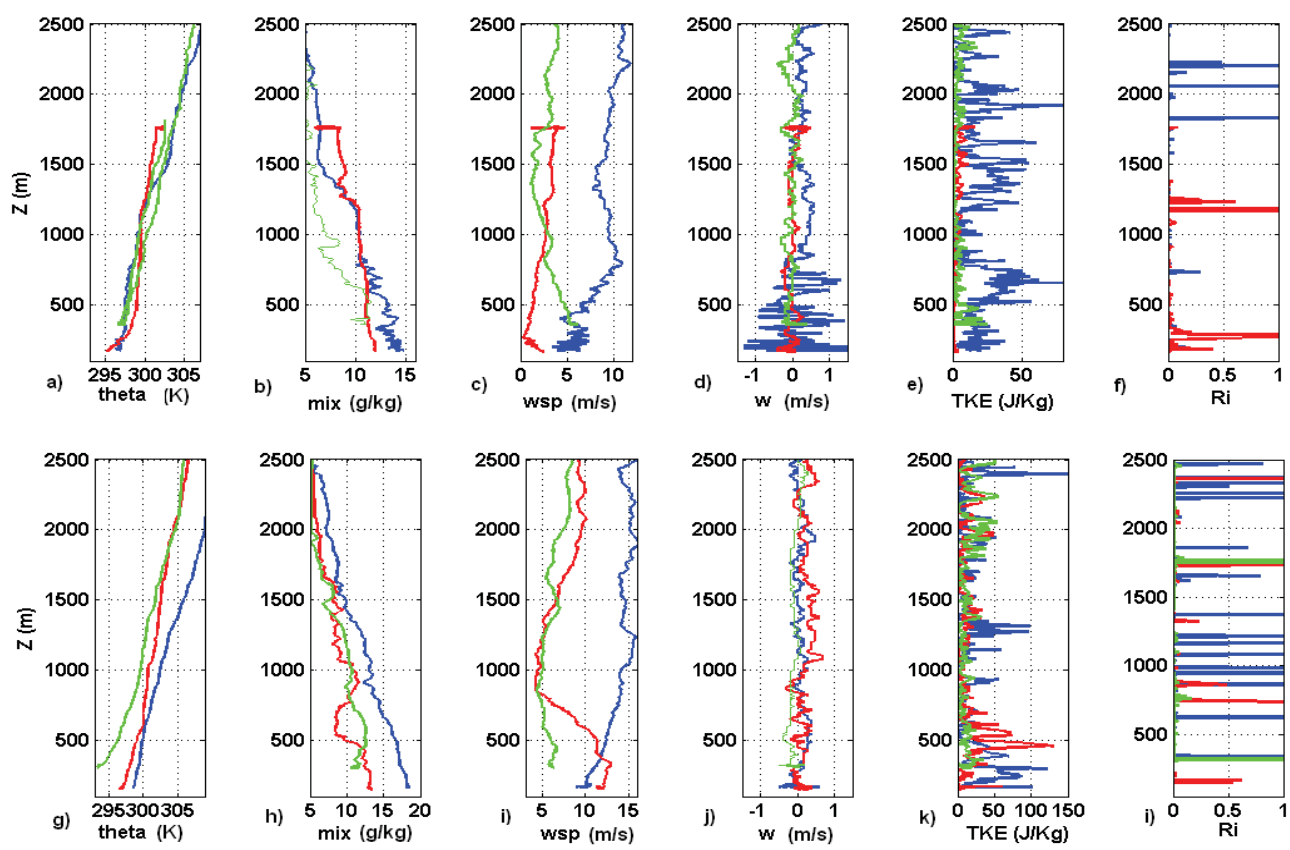

ACPD

$12,2395-2434,2012$

\section{Transport and outflow to the North \\ Atlantic during ICARTT 2004}

S. R. Davis et al.

Fig. 7. Aircraft profiles over the coastal GOM of (a) potential temperature, (b) water vapor mixing ratio (c) horizontal wind speed (d) vertical wind speed, (e) turbulent kinetic energy, and (f) Richardson number values. Corresponding observations of the same parameters over the western Atlantic/ eastern GOM are shown in (g)-(I). Blue lines represent observations on 20 July, red 21 July and green 22 July.

\section{Title Page}

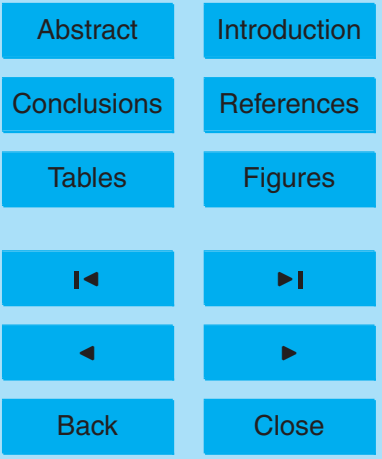

Full Screen / Esc

Printer-friendly Version

Interactive Discussion 
a)

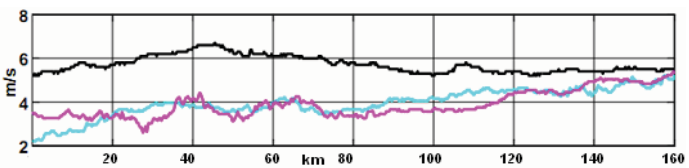

b)

c)
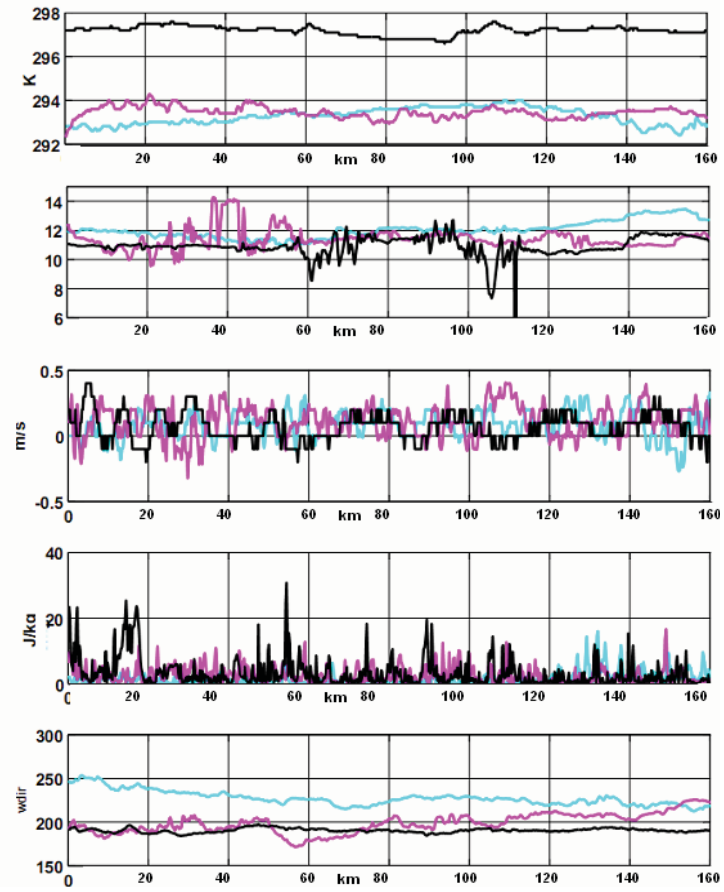

Fig. 8. Physical characteristics of the NYC plume layer observed during transects by the P-3 on 21 and 22 July over the GOM. Shown are (a) horizontal wind speed (b) potential temperature (c) water vapor mixing ratio, (d) vertical wind speed (e) turbulent kinetic energy and (f) wind direction. Cyan lines designate observations from the coastal GOM transect on 21 July, magenta lines the oceanic GOM transect on 21 July, and black lines the central GOM transect on 22 July.
ACPD

12, 2395-2434, 2012

\section{Transport and outflow to the North Atlantic during ICARTT 2004}

S. R. Davis et al.

\section{Title Page}

Abstract

Introduction

Conclusions

References

Tables

Figures

14

Back

Close

Full Screen / Esc

Printer-friendly Version

Interactive Discussion 


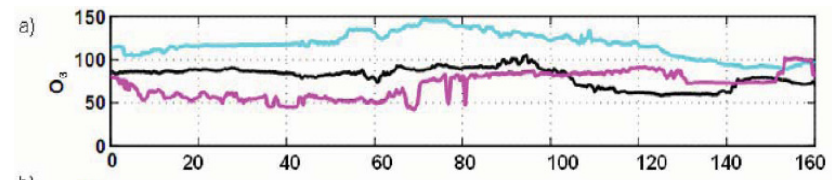

\section{ACPD}

b)
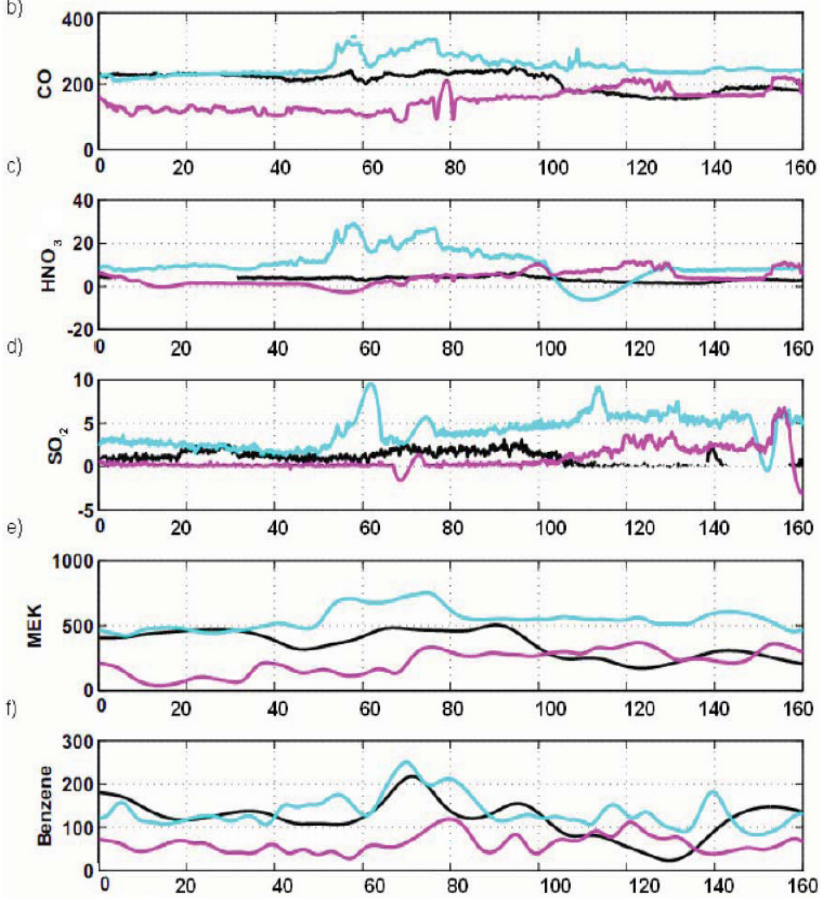

Fig. 9. Trace gas observations of (a) $\mathrm{O}_{3}$, (b) $\mathrm{CO}$, (c) $\mathrm{HNO}_{3}$, (d) $\mathrm{SO}_{2}$, (e) $\mathrm{MEK}$ and (f) Benzene within the NYC plume layer as observed in horizontal transect performed by the P-3 on 21 and 22 July. Cyan lines designate the coastal GOM transects and magenta lines the open ocean GOM transects on 21 July. Black lines designates made during a transect over the central GOM on 22 July.

\section{Transport and outflow to the North Atlantic during ICARTT 2004}

S. R. Davis et al.

\section{Title Page}

Abstract

Introduction

Conclusions

References

Tables

Figures

14

4

Back

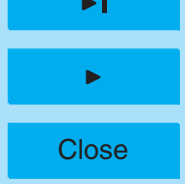

Full Screen / Esc

Printer-friendly Version

Interactive Discussion 

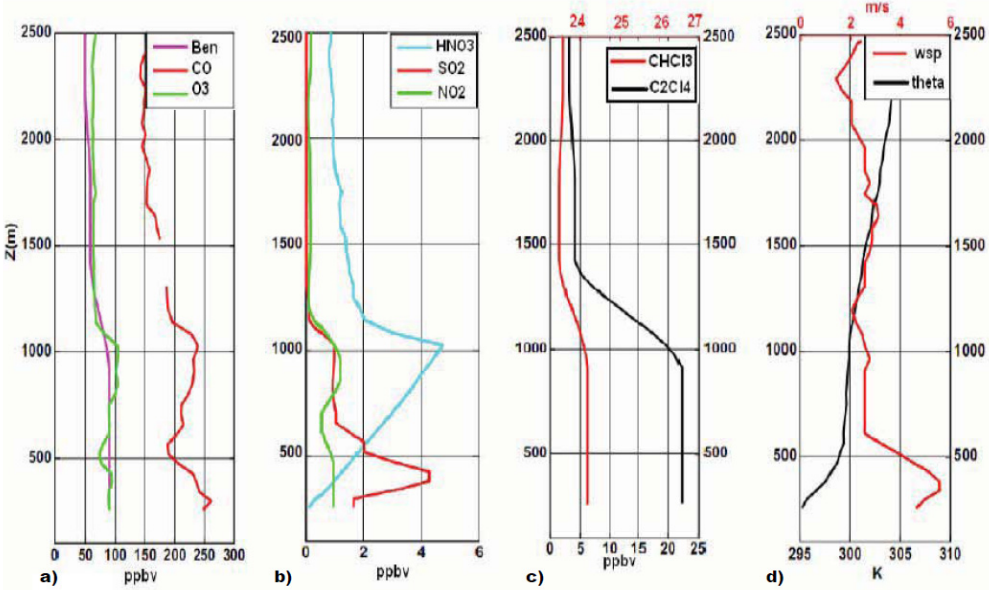

Fig. 10. Cross-platform observations of the plume by the NASA DC-8, Shown are profiles of (a) primary trace gases $\mathrm{O}_{3}, \mathrm{CO}$ and Benzene as well as (b) $\mathrm{HNO}_{3}, \mathrm{SO}_{2}$, and $\mathrm{NO}_{2}$. Profiles of signature halocarbons $\mathrm{CH}_{3} \mathrm{Cl}_{2}$ and $\mathrm{C}_{2} \mathrm{Cl}_{4}$ are shown in (c) With physical parameters of wind speed and potential temperature in (d).

\section{ACPD}

12, 2395-2434, 2012

\section{Transport and outflow to the North Atlantic during ICARTT 2004}

S. R. Davis et al.

\section{Title Page}

\section{Abstract}

Introduction

Conclusions

References

Tables

Figures

14

Back

\section{Full Screen / Esc}

Printer-friendly Version

Interactive Discussion 
a)

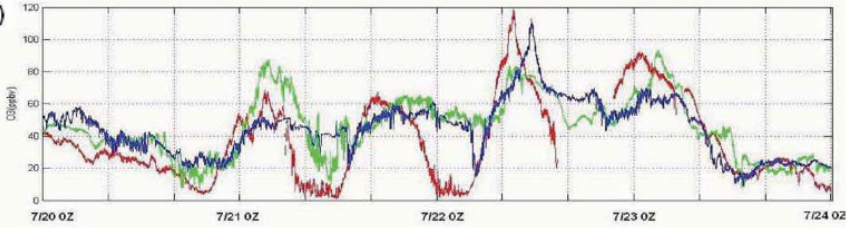

\section{ACPD}

12, 2395-2434, 2012

\section{Transport and outflow to the North Atlantic during ICARTT 2004}

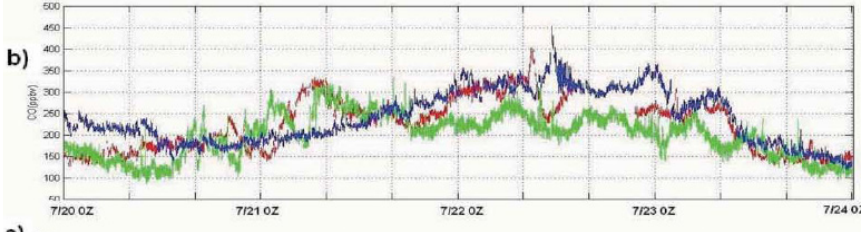

S. R. Davis et al.
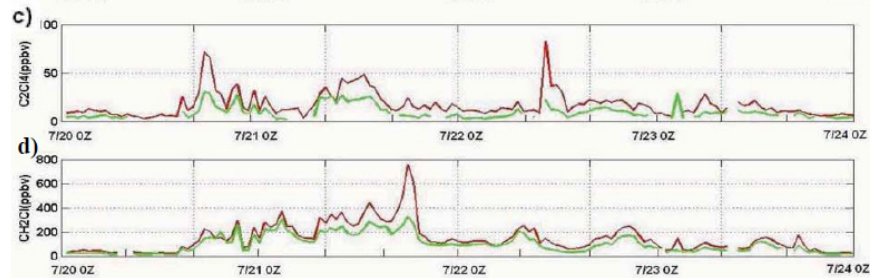

e)

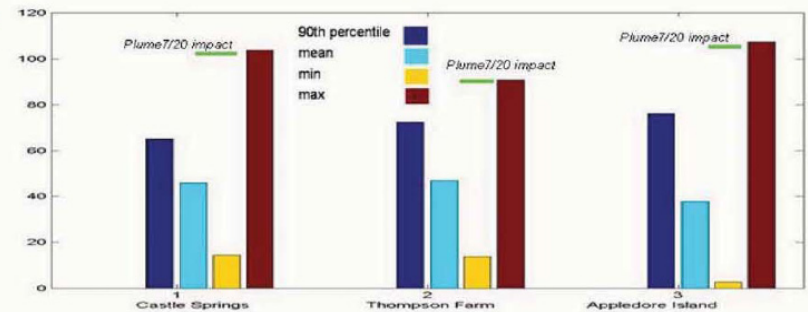

Fig. 11. Surface observations from the ICARTT campaign and observation statistics for the summer of 2004. Shown are measurements of (a) $\mathrm{O}_{3}$ and (b) $\mathrm{CO}$ at three AIRMAP stations: TFR (red), AIS (green), and CSP (blue). Canister observations of (c) $\mathrm{C}_{2} \mathrm{Cl}_{4}$ and (d) $\mathrm{CH}_{2} \mathrm{Cl}$ taken at TFR and AIS are also shown for the same time period. Statistics of the surface $\mathrm{O}_{3}$ (in ppbv) for the summer of 2004 and the relative impact of the 20 July plume are presented in (d). Green lines indicate the peak values observed at each station during the 20 July plume's influence which were equivalent to the maximum values measured at each station that summer.

Title Page

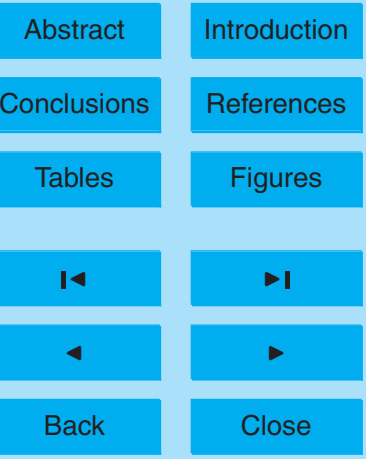

Full Screen / Esc

Printer-friendly Version

Interactive Discussion 
a)
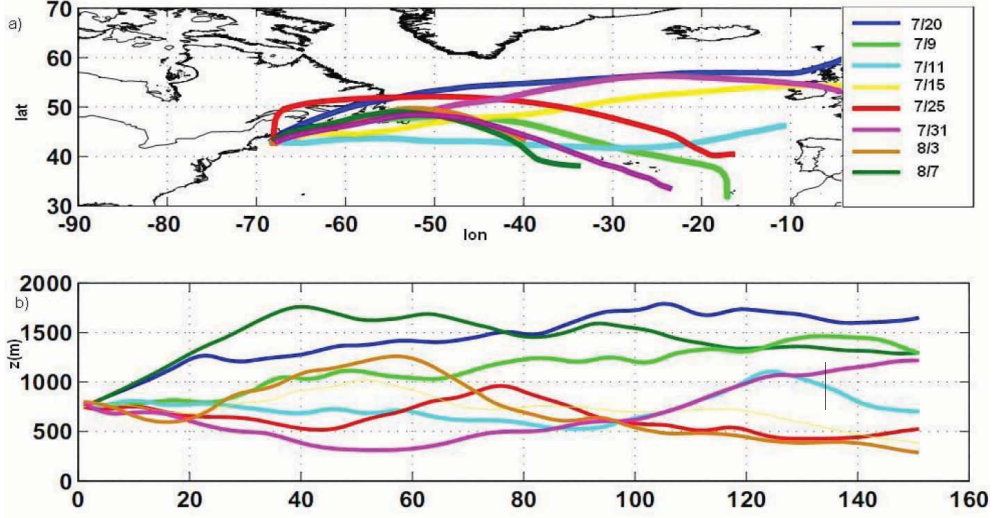

\begin{tabular}{|lcccccccc|}
\hline Date & $7 / 9$ & $7 / 11$ & $7 / 15$ & $7 / 20$ & $7 / 25$ & $7 / 31$ & 813 & $8 / 7$ \\
\hline O3 (ppbv) & 80 & 85 & 122 & 150 & 93 & 98 & 105 & 163 \\
CO(ppbv) & 190 & 160 & 298 & 398 & 220 & 205 & 225 & 390 \\
& & & & & & & & \\
\hline
\end{tabular}

Fig. 12. (a) HYSPLIT model trajectory for the 20 July plume (blue) upon leaving the GOM on 22 July and (b) model altitudes. Also shown are model trajectories for similar plumes encountered by the P3 over the GOM on 9, 11, 15, 25, 31 July, 3, and 7 August. (c) 90 percentile values of $\mathrm{O}_{3}$ and $\mathrm{CO}$ observed within these other potential LLO plumes observed by the P3 over the GOM are reported.
ACPD

12, 2395-2434, 2012

\section{Transport and outflow to the North Atlantic during ICARTT 2004}

S. R. Davis et al.

\section{Title Page}

\section{Abstract}

Introduction

Conclusions

References

Tables

Figures

14

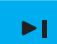

$<$

Back

Close

\section{Full Screen / Esc}

Printer-friendly Version

Interactive Discussion 